De Niz, M., Meehan, G. R. and Tavares, J. (2019) Intravital microscopy: imaging host-parasite interactions in lymphoid organs. Cellular Microbiology, 21(12), e13117.

There may be differences between this version and the published version. You are advised to consult the publisher's version if you wish to cite from it.

This is the peer reviewed version of the following article:

De Niz, M., Meehan, G. R. and Tavares, J. (2019) Intravital microscopy: imaging host-parasite interactions in lymphoid organs. Cellular Microbiology, 21(12), e13117. (doi: 10.1111/cmi.13117)

This article may be used for non-commercial purposes in accordance with Wiley Terms and Conditions for Self-Archiving.

http://eprints.gla.ac.uk/196282/

Deposited on: 16 September 2019

Enlighten - Research publications by members of the University of Glasgow http://eprints.gla.ac.uk/ 
De Niz Mariana (Orcid ID: 0000-0001-6987-6789)

Meehan Gavin R. (Orcid ID: 0000-0001-9855-6565)

\title{
Intravital microscopy: Imaging host-parasite interactions in lymphoid organs
}

\author{
Mariana De Niz ${ }^{1 \#^{*}}$, Gavin R. Meehan ${ }^{2}$, Joana Tavares ${ }^{3,4}$
}

${ }^{1}$ Institute of Cell Biology, Heussler Lab, University of Bern, Bern, Switzerland

${ }^{2}$ Wellcome Centre for Integrative Parasitology, University of Glasgow, Glasgow, UK

${ }^{3}$ i3S-Instituto de Investigação e Inovação em Saúde, University of Porto, Porto, Portugal

${ }^{4}$ IBMC-Instituto de Biologia Molecular e Celular, University of Porto, Porto, Portugal

\# Current affiliation: Instituto de Medicina Molecular - João Lobo Antunes, Faculty of

Medicine, University of Lisbon, Lisbon, Portugal

*Corresponding author: Mariana De Niz, mariana.deniz@medicina.ulisboa.pt

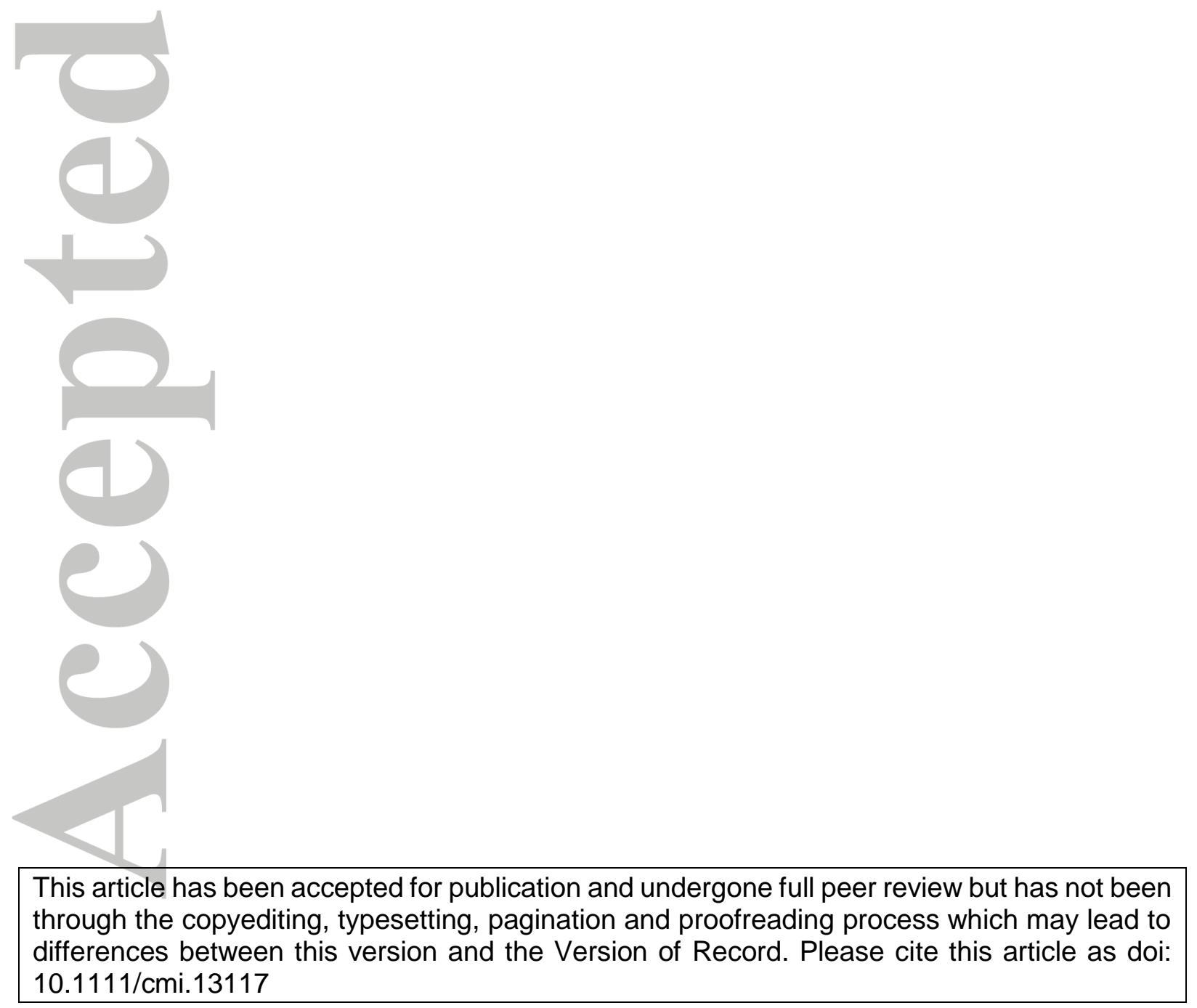




\section{Abstract}

Intravital microscopy allows imaging of biological phenomena within living animals, including host-parasite interactions. This has advanced our understanding of both, the function of lymphoid organs during parasitic infections, and the effect of parasites on such organs to allow their survival. In parasitic research, recent developments in this technique have been crucial for the direct study of host -parasite interactions within organs at depths, speeds, and resolution previously difficult to achieve. Lymphoid organs have gained more attention as we start to understand their function during parasitic infections and the effect of parasites on them. In this review, we summarize technical and biological findings achieved by intravital microscopy with respect to the interaction of various parasites with host lymphoid organs, namely the bone marrow, thymus, lymph nodes, spleen, and the mucosa-associated lymphoid tissue, and present a view into possible future applications.

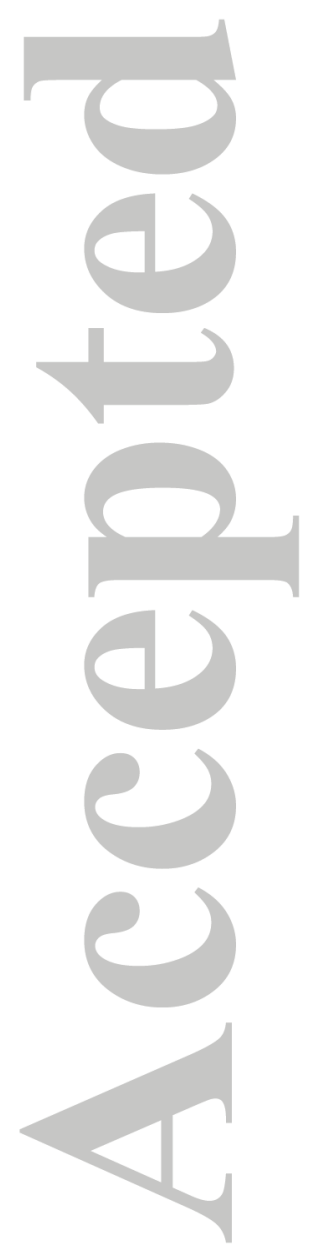




\section{Introduction}

Intravital microscopy (IVM) allows visualization of organs in living animals, down to subcellular resolution, to study cellular interactions, cell dynamics, motility, adhesion, rheology, and anatomical changes in different tissue compartments through time. Major advances in imaging have allowed more organs, and a wider range of physiological phenomena, to be visualized in vivo (reviewed by De Niz et al., 2019). Amongst the most studied systems by IVM is the immune system (reviewed by Secklehner et al., 2017). Altogether, various methods have been developed to study lymphoid organs, and the voyage of immune cell populations across the body of living animals upon challenges including tumours, infection, and inflammation (Chtanova et al., 2014; Chtanova et al., 2009, 2008; Hampton et al., 2015; Ladi et al., 2008; Torcellan et al., 2017).

Immune cells are organized within primary and secondary lymphoid organs, which are vital for innate and adaptive immunity. Primary lymphoid organs (PLOs) include two anatomically complex tissues: the bone marrow and the thymus, where lymphocyte differentiation and maturation occurs. Secondary lymphoid organs (SLOs) include the lymph nodes, spleen, and mucosa associated lymphoid tissues (MALT). These organs host diverse populations of functionally mature, naïve lymphocytes, and are optimally localized across the body to enable efficient surveillance, detection of, and response against foreign antigens (reviewed by Ruddle and Akirav, 2009). In parasitology, primary and secondary lymphoid organs have been the focus of interest in three main contexts: immune response generation upon parasitic infection; organ invasion and remodelling by parasites; and the advantages of tropism for parasite biology. In this review, we will focus on key findings on parasite and hostimmune cell interactions, visualized within primary and secondary lymphoid organs using IVM. Equally, we will discuss the advances on surgical procedures, optical windows, and imaging platforms to visualize these organs.

\section{Primary lymphoid organs in parasitic infections}

The bone marrow and thymus are the PLOs where the largest part of lymphocyte development occurs. Hosting complex interactions between bone and immune compartments, the bone marrow is critical for haematopoiesis, immunological memory and bone regeneration. Critical for the development of T cells, the thymus is vital for the generation of strong, yet selftolerant, adaptive immune responses. Below, we discuss the relevance of performing IVM in 
these organs, available techniques, and key biological findings obtained by IVM in the context of parasitology (summarized in Figure 1).

Biological relevance of the bone marrow

The bone marrow is amongst the organs where IVM has permeated the least, perhaps because of the challenges it represents for imaging. However, histology techniques combined with human and animal autopsies have shown that the bone marrow can influence pathology related to parasitic infections and in some cases, is even a key niche for parasite development. Direct and indirect bone marrow involvement in pathology has been suggested for parasites including Plasmodium spp., (Baro et al., 2017; De Niz et al., 2018; Duffier et al., 2016; Farfour et al., 2012; Joice et al., 2014; Lee et al., 2017; Lee et al., 2018; Mayor and Alano, 2015; Messina et al., 2018; Neveu et al., 2018; Alano, 2017; Rogers et al., 2000; Smalley et al., 1981; Waseem et al., 2016; Wickramasinghe et al., 1987), Toxoplasma gondii (Brouland et al., 1996), Leishmania spp., (Ali and Hussain, 2014; Hellal and Kundu, 2013; Kumar et al., 2007), Schistosoma spp., (Azevedo et al., 2015; Jones and Leday, 2014; Kamal, KA et al., 1989), and Trypanosoma spp. (Baena Terán et al., 2012; Bockstal et al., 2011a, 2011b; Carbajosa et al., 2017; De Diego et al., 1998; Felizardo et al., 2018; Habila et al., 2014; Mabbott and Sternberg, 1995; Müller et al., 2018; Obishakin et al., 2014; Souza et al., 2014; Stijlemans et al., 2016).

The bone marrow is a heterogeneous environment. Within this organ, the stroma provides the structural and chemical niche that supports survival, differentiation and proliferation of pluripotent hematopoietic stem cells (Calvi et al., 2003; Erslev, 1971; Hackney et al., 2002; Lemischka and Moore, 2003; Trentin, 1971; Zhang et al., 2003). In addition, the bone marrow possesses a dense vascular network, which occupies about $30 \%$ of this tissue's volume. This vascular network is largely heterogeneous, with sinusoidal blood vessels being the most prominent vessel type (Itkin et al., 2016; Spencer et al., 2014). This is relevant in the context of parasite colonization, as the sinusoids are characterized by specific haemodynamics, including slow flow rate and high permeability (Itkin et al., 2016; Jung et al., 2018), which affect whether and how parasites cross the vascular endothelium and establish in the bone marrow.

Bone marrow studies envisaging the use of IVM must consider three key aspects: a) the heterogeneity of the bone marrow niche across the body; b) the suitability and comparability of animal models with human bone marrow composition; and c) accessibility for IVM, which varies across bone locations, making some sites more accessible for imaging.

This article is protected by copyright. All rights reserved. 
Methods for IVM-based visualization of the bone marrow

A commonly preferred site for bone marrow IVM is the calvarium, between the sagittal suture bifurcation and the intersection of sagittal and coronal sutures (Figure 1A,i). Historically, bone marrow imaging was first performed in the calvarium (Mazo et al., 1998). This location is preferred mostly because it provides easy surgical access, and the calvarial bone marrow is sufficiently thin and transparent to allow light penetration for high resolution image acquisition. To perform IVM in the calvarial bone marrow, one of the possible surgical procedures is to open the scalp skin to access the calvarial bone, and then suture after imaging. This method represents a challenge for longitudinal imaging because the scalp must be opened and sutured for each imaging session, causing significant scarring and tissue damage that often induce inflammation, degrade image quality, and limit the number of imaging sessions that can be performed at the same site (Lo Celso et al., 2011). Therefore, it is preferable to pursue methods that, consistent with the $3 \mathrm{R}$ perspective relative to work with living animals, diminish discomfort and damage to the animal. To refine the procedure for improved animal welfare, the mouse calvarial window model was developed. Here, a small section of the scalp is removed, a coverglass is attached to the frontoparietal region of the calvarium, and the exposed skull area is covered with a mixture of dental cement powder and cyanoacrylate glue to prevent re-growth of the membrane layer (Le et al., 2017). Alternatively, the cortical bone can be removed, and only a thin layer of bone left. This removal can be done mechanically, or by laser ablation (Lo Celso et al., 2011, 2009, 2009(1); Turcotte et al., 2014).

In 2009, Köhler et al presented IVM methodology for imaging bone marrow in long bones (Köhler et al., 2009). In their work, the authors argued that although the calvarium had been consistently imaged by IVM, it was unclear whether this area was representative of events taking place in long bones (e.g. the tibia). They described a procedure for imaging the tibia, consisting on removing the skin and muscle on top of the bone with a scalpel and/or an electric drill to obtain a very thin $(30-50 \mu \mathrm{m})$ layer of bone tissue covering the bone marrow (Figure 1A,ii). In this technique, it is important not to damage this thin bone layer, to prevent vascular collapse in the bone marrow cavity. In 2017, an advance for this procedure was published, whereby in addition to the surgical procedure, a medium-to-long-term imaging window could be incorporated (Kim et al., 2017). Conversely, an alternative non-destructive method has been explored to investigate the bone marrow niche, and allows visualization of the intact tibia by two-photon microscopy (Lawson, M.A., et al., 2015). 
A more recent method involves the development of a microendoscopic multi-photon imaging approach to perform longitudinal imaging deep within the bone marrow (LIMB) at various anatomical locations, including the calvarium, the tibia, and the femur (Reismann et al., 2017) (Figure 1A,iii). This approach consists on surgically implanting into the mouse femur, a biocompatible fixation plate containing a gradient refractive index (GRIN) lens. This setup is based on a fixation plate originally developed to stabilize the femur after an osteotomy (Matthys and Perren, 2009). Two types of setups were designed to account for tissue heterogeneity in different areas, allowing access to diaphyseal (mid-section of the long bone) or metaphyseal (narrow portion of the long bone) regions. Moreover, a varying length of the endoscopic tubing allows imaging at different depths of the bone marrow. The lenses are permanently glued to titanium tubes mounted on the fixation plate. Window types, and their advantages and limitations, are summarized in Table $\mathbf{1 .}$

Biological findings in parasitology by IVM: the bone marrow

Various parasites home to the bone marrow including Leishmania spp., Trypanosoma spp., Schistosoma spp., and Plasmodium spp. Histology studies on autopsies from humans, cattle and rodent models, have shown that either by their presence alone, or indirectly due to systemic effects, some of these parasites induce drastic changes in various bone marrow compartments. Reported changes include hypercellular marrow, granulomas, lymphoid nodules, fibrosis, and even necrosis in Leishmania infections, all of which correlate with poor prognosis (Haque et al., 2018; Hellal and Kundu, 2013; Kumar et al., 2007). More recently, a murine model of visceral leishmaniasis explored for the first time how CD4+T cell-mediated immunopathology contributes to repression of medullary erythropoiesis in the bone marrow niche, resulting in affected hematopoietic competence and anaemia - one important sequela of L. donovani infections (Preham et al., 2018). T. cruzi, T. brucei, T. vivax, and T. congolense also affect the bone marrow, and induce both acute and chronic effects throughout infection. These include anaemia, thrombocytopenia, leukocytosis, reticulocytosis, and bone marrow hypoplasia (Bockstal et al., 2011b, 2011a; Marcondes et al., 2000; Ojok et al., 2001; reviewed by Silva Pereira et al., 2019). Among other parasites, Schistosoma eggs and Toxoplasma have been detected directly on human bone marrow (Brouland et al., 1996; Jones and Leday, 2014). In rodent models, the presence of Schistosoma influences differentiation at the progenitor level, resulting in induced granulopoietic activity (Joshi et al., 2008). This is thought to be highly linked with maturation of Schistosoma worms, and oviposition (Azevedo et al., 2015; Elkhafif 
et al., 2010; Kamal et al., 1989). To our knowledge, neither Leishmania spp., Trypanosoma spp., Toxoplasma gondii, or Schistosoma spp. have been visualized in the bone marrow using IVM.

In Plasmodium-infected humans, non-human primates, and mice, both asexual stages and gametocytes of Plasmodium have been found in the bone marrow during blood stages of infection. The presence of parasites and parasite products has been associated with pathology including bone loss (Lee et al., 2017), anaemia, and immune dysregulation (Waseem et al., 2016).

However, the main interest in the bone marrow, particularly in recent years, has been in the context of Plasmodium gametocyte maturation. P. falciparum has five morphologically distinct stages of maturation (I-V), of which only the last stage (V) is present in peripheral circulation. For some time, the anatomic site allowing homing of immature gametocytes, remained unknown. In the early 1980s, various studies performed in either bone marrow aspirates or autopsies from human patients showed enrichment of immature Plasmodium gametocytes in the bone marrow extravascular space (Smalley et al., 1981), and Plasmodium sequestration in bone marrow sinusoids (Wickramasinghe et al., 1987).

Only in the last decade has Plasmodium transmission biology research re-gained great momentum, leading to a large number of questions regarding Plasmodium interactions in the bone marrow, including mechanisms of extravasation, development, and egress (Aguilar et al., 2014; Aingaran et al., 2012; Farfour et al., 2012; Joice et al., 2014; Lavazec, 2017; Lavazec et al., 2013; Lavazec and Alano, 2014; Messina et al., 2018; Naissant et al., 2016; Neveu et al., 2018; Ramdani et al., 2015; Rogers et al., 2000). Beyond P. falciparum, the bone marrow has been shown to be an important niche for $P$. vivax development, including gametocyte maturation and asexual development responsible for chronicity (Baro et al., 2017; Markus, 2018; Mayor and Alano, 2015; Obaldia 3rd et al., 2018).

While Plasmodium gametocyte maturation dynamics had previously not been addressed in detail using animal models, three important advances were achieved over the last 3 years: a) the use of humanized mouse models to study $P$. falciparum gametocyte dynamics (Duffier et al., 2016); b) the demonstration that organs involved in erythropoiesis, including the bone marrow are an important reservoir for rodent malaria gametocytes (De Niz et al., 2018; Lee et al., 2018), and c) the use of IVM to study the dynamics of gametocyte maturation including extravasation, maturation, and egress (De Niz et al., 2018). The IVM study showed that bone locations enriched with red marrow were preferentially colonized by $P$. berghei, and that bone marrow sinusoids are key sites for sequestration and invasion. Within the bone 
marrow parenchyma, $P$. berghei gametocytes mature in the proximity of erythroblastic islands, consistent with observations in human autopsies (Joice et al., 2014). IVM showed that as infection progressed, vascular leakage contributes to the entry of sexual and asexual parasite stages to the extravascular space. Finally, mature gametocyte re-entry to the peripheral blood was observed, and was shown to require great deformability (De Niz et al., 2018) (findings are summarized in Figure 1B).

Altogether, the bone marrow represents a puzzling environment so far greatly understudied in parasitology, for which IVM could contribute significantly in the context of immune responses, host-pathogen interactions, chronic and acute BM remodelling, parasite latency, and drug delivery.

Biological relevance of the thymus

The thymus is a primary lymphoid organ which supports the 'education' of $\mathrm{T}$ lymphocytes, resulting in a T cell pool that is self-restricted and self-tolerant. Anatomically, the thymus is located in front of the heart, and behind the sternum (Figure 1C,i). It consists of two merged lobes surrounded by a capsule. The lobes have a dense outer cortex, and an inner medulla. Both the cortex and the medulla are populated by cells of hematopoietic origin, and thymic stromal cells, including epithelial cells. These epithelial cells are essential for the successful selection of a $\mathrm{T}$ cell repertoire that is capable of antigen recognition, and of distinguishing self from foreign. The cortex supports the early events of $\mathrm{T}$ cell development following their migration out of the bone marrow, including $\mathrm{T}$ cell receptor gene rearrangement and positive selection. The medulla supports the late steps of $\mathrm{T}$ cell development, including negative selection rounds necessary to eliminate autoreactive T cells. Mostly in the medullary region, thymic dendritic cells play a key role in the establishment of central tolerance by presenting a broad range of self-antigens. A high affinity interaction with self-antigen-specific thymocytes results in thymocyte death, avoiding self-reacting thymocytes from differentiating into mature T cells (reviewed in Oh and Shin, 2015). Additional to specific cell interactions, hormones and cytokines present in the thymic environment regulate $\mathrm{T}$ cell maturation, while strict chemokine expression directs cell migration within the thymus, and egress of mature $\mathrm{T}$ cells to the periphery once their development is complete (Bunting et al., 2011). 
Methods for IVM-based visualization of the thymus

Although $\mathrm{T}$ cell responses during infection are a relevant topic for various fields of parasitology, the thymus has not directly been imaged by IVM in situ. Due to its anatomical location, the thymus presents important challenges for direct and continuous visualization. To circumvent such challenges, a frequently used alternative has been the transplantation of the thymus to the kidney capsule (Caetano et al., 2012). After acceptance of the thymus, the transplanted kidney is exposed, fixed in a stereotactic organ holder, and kept under physiological conditions for in vivo imaging (Figure 1C,ii). To prevent the kidney from returning to its original position, improved methods suggest closing the lateral sides of the skin incision with stitches (Caetano et al., 2012). Although the transplanted thymus approach has been successfully used in various studies, limitations of this approach include the complexity of the surgery required for transplantation, and the fact that different corporal conditions exist in the surrounding environment of a thymus transplanted in the kidney as opposed to a thymus located in the thoracic cavity (Aghaallaei and Bajoghli, 2018). Ex vivo alternatives to the complex transplantation procedure include extraction of individual thymic lobes perfused with oxygenated medium, followed by imaging by two photon microscopy (Ladi, E., et al 2008), and imaging thymic slices (Bousso et al., 2002; Bousso and Robey, 2004; Ehrlich et al., 2009; Ross et al., 2016). Both methods have been used to observe thymocyte dynamics shortly after extraction. A limitation reported by the various groups who have used this method is that the cytokine and chemokine millieu of the slices might not be representative of the intact thymic environment in vivo. Finally, another alternative for imaging the thymus, is the use of teleost fish models including zebrafish and medaka. These models have allowed performing timelapse imaging of the entire thymus, and visualization of $\mathrm{T}$ cell dynamics at different stages of development (Bajoghli et al., 2015; Hess and Boehm, 2012). Window types, and their advantages and limitations, are summarized in Table $\mathbf{1 .}$

Biological findings in parasitology by IVM: the thymus

To our knowledge, IVM has not been used to study the thymus in the context of parasitology. However, various parasites invade the thymus, causing important disruptions in this organ's delicate architecture, and infection has important implications for T cell mediated responses. This suggests that IVM implementation to study this organ might be highly relevant, and worth pursuing. Parasites known to involve the thymus include T. cruzi (Cotta-de-Almeida et al., 2003; Farias-de-Oliveira et al., 2013b, 2013a; Leite-de-Moraes et al., 1992; Mendes-da- 
Cruz et al., 2006, 2003; Pérez et al., 2007; Savino et al., 1989), Plasmodium spp., (de Meis et al., 2012; Francelin et al., 2011; Gameiro et al., 2010) and Toxoplasma gondii (Huldt et al., 1973; Kugler et al., 2016; reviewed by Nunes-Alves et al., 2013; Savino, 2006) (Figure 1D).

Infections with $T$. cruzi, T. gondii, and P. berghei cause thymic atrophy by different processes (de Meis et al., 2012; Farias-de-Oliveira et al., 2013a, 2013b; Francelin et al., 2011; Nunes-Alves et al., 2013). Infection of the thymus by T. cruzi or P. berghei results in significant changes to the extracellular matrix, as well as increased fibronectin, laminin deposition, and chemokine ligand expression (Cotta-de-Almeida et al., 2003; Gameiro et al., 2010; Mendesda-Cruz et al., 2006; Savino et al., 1989) (Figure 1E). Altogether, both infections result in accelerated intrathymic $\mathrm{T}$ cell migration, and premature release of $\mathrm{T}$ cell populations to the periphery (Cotta-de-Almeida et al., 2003; Mendes-da-Cruz et al., 2003), some of them being potentially autoimmune (Morrot et al., 2012). T. gondii also contributes to thymic atrophy, by inducing destruction of the thymic epithelium, and of the overall architecture of the thymus. This has mostly been associated with a profound and persistent destruction of the CD4+ T cell pool, which contributes to an immunocompromised state and to the maintenance of chronic $T$. gondii infection (Kugler et al., 2016) (Figure 1E).

None of the studies performed so far have studied parasite interactions with the thymic resident cells, nor the effects of parasite presence on events such as lymphocyte migration and development in vivo. IVM would enable a better understanding on T cell-mediated immunity, and alterations during infections due to thymic compromise.

\section{Secondary lymphoid organs in parasitic infections}

Following their development in the primary lymphoid organs, competent lymphocytes populate secondary lymphoid organs such as the lymph nodes, the spleen, and the MALT. These organs have a key distribution across the body to allow surveillance and efficient responses upon challenges including infections.

Biological relevance of the lymph nodes

Lymph nodes (LNs) are secondary lymphoid organs distributed throughout the body that serve as critical hubs for the induction of cellular and humoral immune responses. LNs are divided into discrete regions: the capsule, made of connective tissue; the cortex (divided into an outer and inner region) which harbours $\mathrm{T}$ and $\mathrm{B}$ cells, as well as dendritic cells and macrophages; and the inner medulla, which harbours plasma cells. LNs form an interface 
between the blood and lymphatic systems. Cells enter the LNs through two main routes: the lymphatic vessels or specialized blood vessels called high endothelial venules. The capacity of lymph nodes to trap and filter particulate antigens serves not only to concentrate antigen for B and T cell presentation but also to contain pathogens' systemic spread (Moran et al., 2019).

Methods for IVM-based visualization of the lymph nodes

Murine LNs have been extensively studied by IVM, and successfully imaged in the context of parasitology. Previous work has identified 22 LN sets in mice (Figure 2A): 4 in the head and neck region (mandibular, accessory mandibular, superficial parotid, and cranial deep cervical); 2 in the forelimb (proper axillary, accessory axillary); 3 in the hind-limb (subilliac, sciatic, popliteal); 3 at the intrathoracic region (cranial mediastinal, tracheobronchial and caudal mediastinal); and 10 in the abdomen (gastric, pancreaticoduodenal, jejunal, colic, caudal mesenteric, renal, lumbar aortic, lateral iliac, medial iliac, and external iliac) (Van den Broeck et al., 2006). One of the main drawbacks for IVM is that while enlarged LNs can be readily identified, the LNs in mice under homeostatic conditions are difficult to distinguish from surrounding adipose and connective tissues. Furthermore, not all LNs are equally accessible, and some have been preferred for intravital studies in various fields - in particular the popliteal LN. Plasmodium and Leishmania IVM imaging have been mostly done in the popliteal LN (Bajénoff et al., 2006; Radtke et al., 2015); ex vivo imaging of T. brucei infected was done in the cervical and mandibular LN (Caljon et al., 2016), while Toxoplasma gondii was imaged by IVM in the mesenteric LN (Chtanova et al., 2008). Due to the vast possibilities for imaging LNs in situ by IVM, this section will focus on the technical details of visualization of the popliteal LN (Figure 2Bi, Bii (grey circle)) while briefly discussing novel and relevant techniques to investigate alternative locations. Regarding the mesenteric LNs, the surgical procedure and optical windows are equal to those described below for spleen and GALT IVM. As for other organs, successful LN IVM consists on the immobilization of the tissue within a living, anaesthetized mouse without disruption of vascular and lymph flow. This requires good surgical skills, and for some organs, including the LNs, dedicated microscope stages. To overcome potential problems regarding tissue motion, a recent technical development is real-time drift offset correction, which adjusts the positioning of the stage based on pattern matching, allowing certain anatomical landmarks to remain in the same position despite tissue shifts during image acquisition (Vladymyrov et al., 2016). 
The popliteal LNs are located within the popliteal fossa, or knee joint. Various protocols have been developed for surgical exposure and IVM of this LN (Liou et al., 2012; Mempel et al., 2004; Stein and F. Gonzalez, 2017). Three explanations for the preference of this LN over most others for IVM, are a) that detailed methods for surgical exposure and imaging of this site were the earliest developed (Mempel et al., 2004); b) that there is significant lymphatic drainage from the footpad to this $\mathrm{LN}$, making this a good location to visualize antigen and pathogen arrival (reviewed by Nitschke et al., 2008; Stein and F. Gonzalez, 2017); and c) that the popliteal LN is small enough to allow visualization of cell-cell interactions in all 3 compartments (reviewed by Stein and F. Gonzalez, 2017). Following careful hair removal in the area, surgery requires a $2-3 \mathrm{~mm}$ incision at the knee, to expose the extensor tendon. This involves a midline vertical incision through the skin at the mid-calf, and two horizontal incisions at the top of the vertical incision line, to generate skin flaps. To secure different layers of the tissue prior to exposure of the LN, tissue adhesive can be used to glue these layers to the holder, and provide stabilization to the leg for imaging. For stabilization, the knee tendon can be secured between the skin flap holders. The LN then lies within the popliteal fossa, and must be extremely carefully separated from surrounding muscles and adipose tissues. Once exposed, it is crucial to maintain proper body temperature and prevent dehydration. For the latter point, the LN can be submerged in saline prior to coverage with the glass coverslip (Liou et al., 2012; Mempel et al., 2004). Once the mouse is secure in the customized stage, it is advised that the tail is carefully secured, as it will provide stability to the leg while imaging (Figure 2B,i). The mouse can then be imaged using an upright microscope directly above the exposed popliteal LN. Various protocols have been suggested to generate the customized stage that best supports mice for IVM (Liou et al., 2012).

Although not yet used in a context of parasitology, a recent development which could be useful to the field is the chronic lymph node window (CLNW) model, which allows longitudinal imaging of the inguinal LNs (Jeong et al., 2015; Meijer et al., 2017). In their work, Meijer et al designed a stage specifically to allow access to this LN, while preventing rotational changes and respiration or heart-beat induced artefacts during imaging (Figure 2B,ii) (Meijer et al., 2017). The CLNW allows for longitudinal imaging over 14 days, with uncompromised blood flow and/or vessel integrity. This window model was first modified from a chronic mammary fat pad window model (Chauhan et al., 2012; Jeong et al., 2015; Kedrin et al., 2008). It involves the surgical implantation of symmetrical titanium frames that hold the LN 'sandwiched' in-between. These frames are secured via sutures and bolts. The ventral skin covering the $\mathrm{LN}$ is removed, and the $\mathrm{LN}$ separated from the surrounding muscle and fat. A 
coverslip can then be secured in one of the ventral titanium frame, to allow visualization of the LN. It is suggested that mice used for CLNW implantation weigh over $25 \mathrm{~g}$, so that the window does not prevent leg movement. Following CLNW implantation, the mice recover for $48 \mathrm{~h}$. Similarly novel as the CLNW, is a model that circumvents the need for invasive surgery, and allows longitudinal imaging. This novel protocol involves the transplantation of LNs to the ear pinna (Gibson et al., 2012) for direct visualization using multiphoton microscopy. These transplanted LNs maintain the structure, function, and organization of LNs in situ, and have functional lymphatic and vascular supplies thus allowing longitudinal studies of lymphocyte dynamics and antigen presentation, among other phenomena (Figure 2B,iii). Window types, and their advantages and limitations, are summarized in Table $\mathbf{1 .}$

Biological findings in parasitology: the lymph nodes

Vector-borne protozoans inoculated in the skin of the mammalian host, such as Leishmania, Trypanosoma and Plasmodium reach the draining LNs undergoing distinct fates. The first quantitative IVM study of $P$. berghei transmission from mosquito to mammals has shown that in mice only a proportion $(\sim 50 \%)$ of sporozoites, the highly motile parasite stage inoculated by the mosquito, leave the skin (Amino et al., 2006; reviewed in Graewe, S., et al., 2012). Moreover, only sporozoites that invade skin blood vessels find their way to the liver. Sporozoites entering skin lymph vessels stop their journey at the proximal LN, where most are degraded inside CD11c+ dendritic cells (DCs). However, a few parasites invade cells expressing podoplanin (a membrane protein found in lymphatic endothelial cells) where they partially differentiate into exoerythrocytic forms (EEF) (Amino et al., 2006). The skin was also shown to support the development of sporozoites till complete maturation into red blood cells infective forms, a process that was thought to occur exclusively in the liver (Coppi et al., 2011; Gueirard et al., 2010). This implies that the LN draining the inoculation site will receive parasite antigens not just from sporozoites (sporozoites actively reaching the LN or dead sporozoites left in the skin) but also from differentiating parasites (skin EEF aborting at various stages of their development). Regarding the immunological implications of these findings, so far it is known that after an infectious mosquito bite the first cohort of protective CD8+ T cells is primed by DCs in cutaneous LNs (Chakravarty et al., 2007; Obeid et al., 2013). Dynamic in vivo and static imaging has shown the uptake of parasites by LN DC followed by the DC cluster with $\mathrm{CD} 8^{+} \mathrm{T}$ cells. Indeed, $\mathrm{CD} 8^{+} \mathrm{T}$ cells are primed by resident $\mathrm{CD} 8 \alpha^{+} \mathrm{DCs}$ with no apparent role for skin-derived DCs. This study established a critical role for $\mathrm{LN}$ resident $\mathrm{CD} 8 \alpha^{+} \mathrm{DCs}$ in 
$\mathrm{CD}^{+} \mathrm{T}$ cell priming to sporozoite antigens while emphasizing a requirement for motile sporozoites in the induction of $\mathrm{CD}^{+} \mathrm{T}$ cell-mediated immunity (Radtke et al., 2015) (Figure 2C, i and 2D, i ). Altogether. IVM discoveries have changed our view of the malaria preerythrocytic phase and the previously unanticipated role of the skin and draining LN in this phase.

While Plasmodium sporozoites reach the draining LN in the first hour after inoculation in the skin (Amino et al., 2006) African trypanosomes take longer as the first parasites are detected in LN 18 hours after infection with tsetse flies (Caljon et al., 2016). IVM studies revealed that engulfment of trypanosomes by neutrophils at the inoculation site was rarely observed and was restricted to parasites with reduced motility/viability whereas live parasites escape phagocytosis (Caljon et al., 2018) (Figure 2C, ii and 2D, ii). When and how trypanosomes invade lymph vessels remains to be elucidated as well as the cell types with which parasites interact within the LN. Flagellated Leishmania promastigotes are on the other hand rapidly taken up by neutrophils after inoculation in the skin. This was seen for Leishmania species that cause either cutaneous or visceral infection (Peters et al., 2008; Ribeiro-Gomes et al., 2012; Thalhofer et al., 2011, 2010). However, few days after infection the parasites persist in the form of intracellular amastigotes mostly inside monocytes, macrophages and DCs (De Trez et al., 2009; Hurrell et al., 2015; León et al., 2007; Peters et al., 2008). The role of neutrophils in both promoting or supressing host immunity remains controversial and a clear demonstration on whether these cells act as Trojan horse for the dissemination of Leishmania parasites to distant sites remains to be demonstrated in vivo (Ribeiro-Gomes et al., 2012; Ribeiro-Gomes and Sacks, 2012). IVM studies combined with flow cytometry showed that Leishmania mexicana use neutrophils as a safe transient shelter and that this impacts parasitespecific immune response in mice. Indeed, an increase in monocyte-derived DCs in the draining LNs of neutropenic mice was seen and correlated with the subsequent increased frequency of IFN $\gamma$-secreting T helper cells and better parasite control (Hurrell et al., 2015). IVM also elucidated the dynamics of NK cells following Leishmania major infection. NK cells, which reside in both the LN medulla and paracortex in steady state conditions, were shown to be recruited from the blood to the paracortex where they produce IFN-y that activates parasite-specific CD4 ${ }^{+} \mathrm{T}$ cells (Bajénoff et al., 2006) (Figure 2C,iii and 2D, iii).

IVM imaging of Toxoplasma gondii-infected mice has shown that neutrophils are able to migrate in a coordinated manner within the LNs (Chtanova et al., 2008). Cooperative action of neutrophils and parasites egressing from host cells triggers neutrophil swarm formation leading to the removal of macrophages that line the subscapular sinus of the lymph node. These 
results provide insight into the cellular mechanisms that lead to neutrophil swarms and suggest new potential functions for neutrophils in LNs (Chtanova et al., 2008; Coombes and Robey, 2010) (Figure 2C,iv and Figure 2D, iv).

\section{Biological relevance of the spleen}

The spleen is a specialized organ that combines the innate and adaptive immune system within a complex architecture. The structure of the spleen enables it to remove older erythrocytes from circulation, thus constantly maintaining a pool of red blood cells best adapted to transport oxygen and iron across tissues. Equally, the spleen's architecture allows efficient removal of blood-borne microorganisms, including parasites. The spleen is organized into three main compartments: the red pulp, where pathogens and senescent red blood cells are removed from the blood by specialized macrophages; the white pulp, a highly organized lymphoid region composed of $\mathrm{B}$ and $\mathrm{T}$ cell zones; and the marginal zone, which constitutes a bridge between innate and adaptive immune responses due to its specialized macrophage and B cell subsets. The specialized architecture of the spleen is coordinated by the expression of lipid mediators, adhesion molecules, and chemokines, which direct the migration and retention of specific lymphoid subsets across the splenic compartments (Reviewed by (Mebius and Kraal, 2005)).

Methods for IVM-based visualization of the spleen

The spleen presents important challenges for IVM. Two significant microscopy-based limitations imposed by the spleen are a) that the optically dense capsule contributes to significant light scattering, making some anatomical sections of the spleen difficult to access for imaging; and b) that the spleen is highly vascularized and highly complex in its cellular composition, with multiple regions of very fast circulation (Discussed in (Grayson et al., 2001)). Many confocal systems lack the capability of scanning or recording data at a speed rapid enough to allow distinguishing cellular interactions or sub-cellular events at high speed. In other organs, poor penetration depth has been largely addressed by the use of two-photon microscopes, while speed limitations have been overcome to a certain extent, by spinning disc methods, or opto-acoustic deflectors achieving a minimum of 30 frames per second (Discussed in (Grayson et al., 2001)). IVM techniques adapted for spleen imaging not based on fluorescence, but which overcome the above challenges, include optical frequency domain imaging (OFDI) (Kubo et al., 2017; Otake et al., 2018; Yun et al., 2003), and coherent anti- 
Stokes Raman spectroscopy (CARS) (Vogler et al., 2015). The former allows detection of scattering properties of tissues at multiple depths to detect angiogenesis and tissue viability, while the latter uses multiple photons to detect intrinsic molecular vibrations, allowing imaging of chemical structures. These techniques have been used in other areas of research, but remain to be introduced in parasitology. An alternative to these methods, is the use of time- and polarization-resolved fluorescence detection, such as fluorescence lifetime imaging (FLIM), whereby the combination of high-speed acquisition and novel methods of image processing, allow for visualization almost in real time (Niesner et al., 2008).

In terms of imaging windows, various types of setups have been designed to image the spleen. One includes the abdominal imaging window (AIW) for imaging with either an upright or an inverted microscope (Figure 3A,i). In 2012, Ritsma et al developed the abdominal imaging window (AIW), which consists of a titanium ring with a $1 \mathrm{~mm}$ groove on the side, and a coverslip which can be fixed on the top with glue, and exchanged as required (Ritsma et al., 2013, 2012). Following this, the AIW is implanted in the skin and abdominal wall, and held in position by a purse-string suture, which prevents the mice from biting or removing the sutures. The AIW was reported to be used over a maximum of 28 days, without considerable changes in the anatomical position of the window and without disturbing physiological processes. Although the AIW offers major advantages for long term imaging, less complex, temporary windows which simply consist on surgically exposing the organ of interest, hydrating it, and attaching it to a coverslip using glue, can also be used for short-term (4-8 h) imaging. Such setup has been used for Plasmodium imaging, and involves the exposure of the spleen through a small incision on the mouse flank, followed by attachment to a glass coverslip for imaging on an inverted microscope (De Niz et al., 2016; Ferrer et al., 2012) (Figure 3A,ii). While using glue for attaching the abdominal organs is possible for short-term imaging (i.e. no more than 12 hours, continuously), it is not suitable for imaging over a period of days. Alternatively, a vacuum-coupled window can be implemented for imaging using an upright microscope (Figure 3A,iii); or a a glass-bottom cell culture dish, whereby the spleen is exposed and immobilized over sterile saline, allowing use of an inverted microscope (Grayson et al., 2001).

Specific challenges during splenic surgery and exposure include a) that care should be taken to avoid the vasculature while performing the incisions on cutaneous and muscle layers to expose the organ, to prevent bleeding over the spleen during imaging; b) that extreme care should be taken upon pulling the spleen through the muscle, peritoneal, and skin incisions in order to neither compress the spleen vasculature (which would hinder circulation and all chances of visualizing cells in motion), nor to cause bleeding or incisions in the spleen (which 
could be lethal due to rapid exanguination in extreme cases). Moreover, the intercostal incision should be relatively small, because with larger incisions, the risk that the spleen retracts into the abdominal cavity and away from the window is higher. IVM of the spleen upon even minor splenomegaly (often observed in parasitic infections) should be performed with extreme caution, as the tissue is very fragile and could easily rupture.

In addition to the surgical considerations for imaging, an equally important issue is the biological relevance of the mouse spleen relative to the human spleen. Three key differences between the mouse and human spleens include a) that the marginal zone of the human spleen lacks a delimited marginal sinus and is surrounded by an additional perifollicular zone; b) that the human spleen is sinusoidal, while the mouse spleen is less so; and c) that while the mouse spleen is a key organ for erythropoiesis, the human spleen is less so. This has been relevant in the study of malaria, and might equally be so in the study of other parasitic diseases for which animal models exist. Although pathogens including Plasmodium, T. brucei, T. cruzi, Leishmania, Schistosoma, Babesia, Echinococus and Paragonimus cause spleen involvement and pathology, to our knowledge only Plasmodium has been imaged by IVM. Window types, and their advantages and limitations, are summarized in Table 1.

Biological findings in parasitology by IVM: the spleen

As part of its functions, the spleen destroys senescent red blood cells in health, and aids in the detection and immune response formation against blood-borne pathogens. The spleen's involvement in malaria is significant. Splenomegaly is a hallmark of the disease in endemic areas; furthermore, splenectomy both in rodents and humans has been consistently associated with more frequent fever, and higher parasitemias. In 2009, Buffet PA et al discussed a paradigm, arising from studies of the spleen of infected children, whereby the spleen is regarded as a double-edged sword. While retention of Plasmodium rings and uninfected RBCs aids in reducing the risk of cerebral malaria, it also increases the risk of severe malarial anaemia (Buffet et al., 2009). Moreover, because of its role as a blood surveillance organ, it is believed that the presence of the spleen has driven the evolution of a plethora of evasion mechanisms in Plasmodium to avoid destruction. Perhaps the most significant is the parasite's ability to sequester in the peripheral vasculature of multiple organs - a phenomenon responsible for pathology and complications associated with malaria (reviewed by (del Portillo et al., 2012; Engwerda et al., 2016)). Previous work to study Plasmodium in the spleen, ex vivo, has included an ex vivo perfusion system whereby the spleen retained its clearing and processing functions 
and allowed visualization of P. falciparum (Buffet et al., 2006), and a spleen-on-a-chip approach which reproduced splenic basic units (splenon) and areas of fast and slow circulation, where Plasmodium dynamics could be investigated (Rigat-Brugarolas et al., 2014).

To our knowledge, the malaria-infected spleen has been imaged by IVM in four separate studies over the last 6 years. The first spleen IVM study in rodent malaria models focused on the differential remodelling of this organ induced by lethal and non-lethal GFPexpressing P. yoelii strains (Py17XL and Py17X, respectively). A significantly higher number of parasites of the non-lethal strain were detected in the spleen, than those of the lethal strain. This was proven to neither be the result of different blood flow, not differential macrophage activity. The non-lethal strain, however, displayed an adhesive rolling-circle behaviour, while the lethal strain did not. Conversely, FITC-labelled uninfected RBCs and fluorescent beads displayed equal flow patterns in mice infected with either strain (Martin-Jaular et al., 2011) (Figure 3B,i). This differential motion specific to the parasites, together with further MRI, EM and other ex vivo data, led to the conclusion that the non-lethal strain induces a spleen blood barrier of fibroblastic origin, to which Py17X-infected reticulocytes can adhere to, to escape from macrophage clearance. The image-processing pipeline developed to track parasite directionality, residence time, mean velocity, and volumetric blood flow allowing for normalization of erythrocyte and lumen vessel diameters, was made available in parallel to the original study (Ferrer et al., 2012). In line with the aim of investigating Plasmodium interactions with splenic populations, a later study went on to explore the role of DCs in the control of blood stage infections with $P$. yoelii and the chronic malaria model $P$. chabaudi, at different phases of acute and chronic malaria infections. IVM in this study for the first time showed interactions between DCs and CD4+T cells at different phases of acute malaria, and it was the first work suggesting that aside of their role in antigen presentation, DCs also directly participate in the elimination of iRBCs during acute infection (da Silva et al., 2013). Finally, given that sequestration in the vascular endothelium is believed to be a mechanism developed by Plasmodium to avoid passage through the spleen, a recent study used IVM to demonstrate that non-sequestering $P$. berghei lines lacking export-mediating Maurer's cleft resident proteins MAHRP1a and SBP1 do not sequester, and extensively accumulate in the spleens, inducing exacerbated splenomegaly (De Niz et al., 2016) (Figure 3B,ii).

The spleen has recently gained great interest in the context of malaria transmission. Studies in humanized mice infected with P. falciparum (Duffier et al., 2016), and rodent models of malaria infected with $P$. berghei (Lee et al., 2018), have consistently shown increased numbers of immature gametocytes in the spleen. The relevance of this organ for host- 
to-vector transmission, as well as its study in the context of transmission-blocking drugs, remains to be fully explored, and IVM could be an extremely relevant tool for this purpose.

Although various technological improvements now allow for greater penetration depths and faster imaging to record cellular interactions, the greatest improvements likely to impact spleen IVM are image-processing algorithms for events occurring at high speed. In terms of biology, spleen involvement in the context of immunomodulation and immunopathology have received increased interest, and IVM is a key tool to potentially shed light on parasite-mediated responses. Given its relatively easy use, the implementation of this technique to study other parasites in the spleen, might provide interesting insights into other host-pathogen interactions.

Other immune organs: the Mucosa-associated lymphoid tissue (MALT)

The mucosa-associated lymphoid tissue (MALT) is situated along the surface of all mucosal tissues, and is responsible for initiating immune responses to antigens encountered at these sites. About half of the lymphocytes of the immune system are in the MALT, with the most studied of such locations being the gut-associated lymphoid tissue (GALT) (reviewed by (Jung et al., 2010)), the nasopharynx-associated lymphoid tissue (NALT), and the bronchusassociated lymphoid tissue (BALT) (reviewed by (Bienenstock and McDermott, 2005)). These anatomical locations can be divided into two key sites: effector sites and inductive sites. Inductive sites contain secondary lymphoid tissues which support IgA class switching and clonal expansion of B cells in response to $\mathrm{T}$ cell activation. Following activation and $\mathrm{IgA}$ class switching, T and B cells migrate from inductive sites to effector sites. Effector sites are present as diffuse lymphoid tissue along mucosal surfaces, and allow IgA transport across the mucosal epithelium. The functional compartments of the GALT, NALT, and BALT are lymphoid follicles, the interfollicular region, the subepithelial dome region, and the follicle-associated epithelium (reviewed by (Cesta, 2006)).

Various parasites of clinical relevance enter the body via the gastrointestinal route, and interact with the GALT. These include Giardia spp., Toxoplasma gondii, Entamoeba spp., Ascaris spp., Ancylostoma spp., Necator spp., Strongyloides spp., Paragonimus spp., and Cryptosporidium spp. Vector-borne parasites compromising the GALT include Schistosoma spp. Equally, many of these same parasites have an obligatory passage through the lungs, and interact with the NALT and BALT. To our knowledge, only Plasmodium spp. have been visualized by IVM in the lungs. However the findings are outside the scope of this review, and are discussed in a separate review of this mini-series (unpublished). 
Methods for IVM-based visualization of the GALT

The intestines are a crucial site in the life cycle of most orally-transmitted parasites, as well as a main site of pathology for the host. Despite the huge relevance of this site, intestine IVM has not been extensively reported. Aside from the abdominal imaging window (Figure 3A,i), recent work by (Kolesnikov et al., 2015; Xu et al., 2012) described two alternative methods for imaging the intestines and Peyer's Patches. The surgical procedure involves performing a small incision through the skin along the abdominal midline to expose the peritoneal wall, after which an incision to the peritoneal wall itself follows. Next, a section of the intestine was externalized, and an incision made, further exposing the luminal surface. Care should be taken in particular to a) avoid disrupting the mucosal layer and b) avoid damaging the mesentery or mesenteric vasculature. For this purpose, the use of an electrocautery is recommended (Kolesnikov et al., 2015), rather than a scalpel, to seal off vessels damaged during the surgical procedure. Aside of preventing bleeding, controlling intestinal peristaltic movements and the associated motion artefacts is key. Imaging methods to overcome this issue have been discussed (Kolesnikov et al., 2015; Xu et al., 2012). If using an inverted microscope, upon completion of the surgery, the externalized intestine can be sandwiched between a coverslip and sterile gauze at the animal's abdomen. In this setup, the animal's weight stabilizes the tissues and prevents dehydration (Xu et al., 2012). Conversely, an imaging chamber suitable for imaging using an upright microscope can be used, which is arguably better suited for physiological preparations (Kolesnikov et al., 2015). Two key considerations for intestine IVM which differ from other tissues are on one hand, that autofluorescence areas in the mucosal layer exist which may represent challenges for imaging (although such autofluorescence is absent from the epithelia, and the lamina propria). On the other hand, live intestinal tissue is more sensitive to imaging than the skin, spleen, or other tissues which allow long imaging periods. The intestinal tissue reportedly begins to deteriorate within a $3 \mathrm{~h}$ window following surgery and exposure to air. Internal controls to monitor membrane integrity, vascular permeability, and cellular motility are therefore highly recommended during intestinal IVM (Kolesnikov et al., 2015). Similar to ex vivo alternatives for other organs, imaging can be performed in intestinal sections cultured in aerated media (Chieppa et al., 2006; Coombes et al., 2013). The downside of this method is that the vascular, lymphatic, and nervous connections of the tissue are severed, thus preventing a full reproduction of physiological conditions of the intestines. Window types, and their advantages and limitations, are summarized in Table 1. 
To our knowledge, only $T$. gondii has been imaged in the intestines by IVM (Coombes et al., 2013; Watanabe et al., 2018).

Biological findings in parasitology by IVM: the GALT

T. gondii infection occurs via the oral route. Although the most important clinical complications involve the brain and the developing foetus in pregnant women, $T$. gondii first establishes infection in the small intestine after ingestion of cyst-contaminated meat, or oocystcontaminated water. Following entry to the intestine, the parasite must cross the intestinal epithelium, before it can establish a chronic infection in the brain. The study by Coombes et al aimed to investigate the role of motile immune cells in acting as transport vessels for $T$. gondii across tissues (Coombes et al., 2013). Using IVM, they found that neutrophils are recruited to the villi and lumen of the small intestine upon $T$. gondii infection, and are motile reservoirs of live $T$. gondii, contributing to spreading the infection (Figure 3C). RFP-expressing T. gondii parasites were used to infect reporter mice including CD11c-YFP, and LysM-GFP mice to investigate the role of dendritic cells, macrophages, and neutrophils in the spread of $T$. gondii away from the intestine. Complementary ex vivo experiments showed that parasites within neutrophils remained infection-competent. Important additional observations included the existence of hot spots of parasite replication across the small intestine, and an increased parasite density at the tips of the villi (Coombes et al., 2013).

Altogether, this IVM-based finding is fascinating in that it enabled elucidating a Trojanhorse-like mechanism of pathogen spread which might be highly relevant for other parasites also able to cross tissue barriers. Like-wise, besides of the possibility of imaging host-pathogen interactions, reporter animals could be of use to study immunological responses in the intestines. These might be particularly relevant in the context of infection with parasites including hookworms and nematodes.

A more recent study used IVM to investigate the leukocyte's behaviour in the mesenteric circulation, as well as leukocyte-endothelium interactions following infection with T. gondii (Watanabe et al., 2018). The study's key findings were that haemodynamic changes already happen at the beginning of infection, in which molecules such as ICAM1, PECAM1 and P-selectin are upregulated on the vascular endothelium. These not only contribute to the parasite's adhesion and transmigration, but also to leukocyte mobilization within the mesenteric vasculature, resulting in a mild inflammatory response. 
Given the involvement of the gastrointestinal tract and the lungs by a large number of parasites, the relevance of the MALT for pathology and immunity, and the little understanding of the dynamics we have of parasites in these organs, the implementation of IVM has vast potential in the years to come.

\section{Outlook}

In this review we have discussed the relevance of primary and secondary lymphoid organs in parasitic infections, and the knowledge we have gained as a community through the use of IVM to investigate dynamic interactions in organs including the bone marrow, spleen, lymph nodes, and GALT.

Interestingly, an alternative technology that has been explored for two parasites $(T$. gondii and Plasmodium), in the context of lymphoid organs, is the use of organs-on-chip (OOCs), and of organoids. Organoids consist of organ-specific adult mammalian stem cells grown in a three-dimensional structure whilst OOCs are based on a similar principal as organoids, but with the addition of microfluidic systems to allow for the distribution of nutrients and soluble mediators throughout the constructs. The cells in both systems selforganise into morphologically distinct layers that are capable of successfully mimicking organs. One of the major benefits of OOCs is that they can mimic blood flow, allowing for the assessment of shear stress and deformability of circulating cells. The use of a spleen on a chip model demonstrated the poor deformability of $P$. falciparum pRBCs and their ability to occlude narrow vessels (Picot et al., 2015; Rigat-Brugarolas et al., 2014). Another important advance has been the generation of an organoid for the intestinal epithelium to study $T$. gondii interactions with the epithelium and immune cell populations (Derricott et al., 2019). While both organoids and OOCs are still in their infancy, they have great potential for assessing parasite behaviour in a consistent and reproducible manner.

A complementary advantage of IVM, relative to organoids and OOCs is the possibility to study parasite interactions with and effects upon lymphoid organs within the complexity of a full organism. With better imaging platforms allowing faster speed acquisition, better resolution, and increased penetration depth, IVM holds great potential for the study of parasites and their interaction with cells of the immune system across all immune organs. Of great interest is the relevance of the parasites' presence within the bone marrow and thymus, and as 
this may impact immunity, immunopathology, infection chronicity, tolerance, relapses, transmission and virulence among other phenomena involving the immune system of the host, and the relevance of its recognition of parasites. Equally, although various parasites interact with the BALT, NALT, GALT, LNs and spleen, relatively very little has been studied in these organs in a dynamic manner, particularly with respect to parasite homing, cell-cell interactions, organ remodelling, and impact on immune responses and immunopathology. IVM therefore holds great potential for questions on a plethora of parasites including those food-, water-, and soil-borne, entering via the gastrointestinal tract like Giardia, Toxoplasma, Entamoeba, Ascaris, Ancylostoma, Necator, and Cryptosporidium, and vector-borne with involvement of the blood, lungs or gastrointestinal tract, including Leishmania, T. brucei, T. cruzi, Schistosoma, and Plasmodium.

\section{Acknowledgements}

We thank Prof. Friedrich Frischknecht (University of Heidelberg, Germany) for input on this manuscript and Prof. Volker Heussler (IZB, University of Bern, Switzerland), for input and training $(\mathrm{MDN})$ on the techniques here reviewed. We thank Dr. Sara Silva-Pereira (Instituto de Medicina Molecular, Lisbon) careful and constructive comments on this manuscript. We are grateful to Dr. Liana Verinaud (Universidade Estadual de Campinas, Brazil), Dr. Dragana Jankovic, Dr. Alan Sher (NIH/NIAID, USA), Dr. Fidel Zavala (Johns Hopkins University, USA), Dr. Guy Caljon (University of Antwerp, Belgium), Dr. Marc Bajenoff (Centre d'Immunologie Marseille-Luminy, France), Dr. Ellen Robey (University of California, Berkeley, USA), Dr. Nicolas Brancucci (Swiss TPH, Basel, Switzerland) and Dr. Tobias Spielmann (Bernhard Nocht Institute for Tropical Medicine, Germany) for agreeing to our use of their original figures in this review. MDN was funded by Long Term EMBO Postdoctoral fellowship ALTF 1048-2016. GRM was funded by Wellcome Trust grant 095507. JT is funded

by the Portuguese Foundation for Science and Technology (FCT) grants CEECIND/02362/2017 and PTDC/SAU-PAR/31340/2017. Authors declare no conflict of interest. 


\section{References}

Aghaallaei, N., Bajoghli, B., 2018. Making Thymus Visible: Understanding T-Cell Development from a New Perspective. Front. Immunol. 9, 375. doi:10.3389/fimmu.2018.00375

Aguilar, R., Magallon-Tejada, A., Achtman, A.H., Moraleda, C., Joice, R., Cisteró, P., Li Wai Suen, C.S.N., Nhabomba, A., Macete, E., Mueller, I., Marti, M., Alonso, P.L., Menéndez, C., Schofield, L., Mayor, A., 2014. Molecular evidence for the localization of Plasmodium falciparum immature gametocytes in bone marrow. Blood 123, 959-966. doi:10.1182/blood-2013-08-520767

Aingaran, M., Zhang, R., Law, S.K., Peng, Z., Undisz, A., Meyer, E., Diez-Silva, M., Burke, T.A., Spielmann, T., Lim, C.T., Suresh, S., Dao, M., Marti, M., 2012. Host cell deformability is linked to transmission in the human malaria parasite Plasmodium falciparum. Cell. Microbiol. 14, 983-993. doi:10.1111/j.1462-5822.2012.01786.x

Alano, P., 2017. The emerging role of the human bone marrow as a privileged developmental niche for the transmission stages of the malaria parasite Plasmodium falciparum. Commentary. Ann Ist Super Sanita 53 (2), 96-99. doi:10.4415/ANN_17_02_03

Ali, N., Hussain, S., 2014. Leishmania donovani bodies in bone marrow. Clin. Case reports 2, 238-239. doi:10.1002/ccr3.97

Amino, R., Thiberge, S., Martin, B., Celli, S., Shorte, S., Frischknecht, F., Ménard, R., 2006. Quantitative imaging of Plasmodium transmission from mosquito to mammal. Nat. Med. 12, 220-4. doi:10.1038/nm1350

Azevedo, C.M., Solano de Freitas Souza, B., Andrade de Oliveira, S., Paredes, B.D., Barreto, E.S., Neto, H.A., Ribeiro dos Santos, R., Pereira Soares, M.B., 2015. Bone marrowderived cells migrate to the liver and contribute to the generation of different cell types in chronic Schistosoma mansoni infection. Exp. Parasitol. 159, 29-36. doi:10.1016/j.exppara.2015.08.005

Baena Terán, R., Arancibia, A., Basquiera, A.L., De La Fuente, J.L., Ricchi, B., de Diller, A.B., 2012. Trypanosoma cruzi in the bone marrow. Br. J. Haematol. 157, 1. doi:10.1111/j.1365-2141.2012.09049.x

Bajénoff, M., Breart, B., Huang, A.Y.C., Qi, H., Cazareth, J., Braud, V.M., Germain, R.N., Glaichenhaus, N., 2006. Natural killer cell behavior in lymph nodes revealed by static and real-time imaging. J. Exp. Med. 203, 619-631. doi:10.1084/jem.20051474

Bajoghli, B., Kuri, P., Inoue, D., Aghaallaei, N., Hanelt, M., Thumberger, T., Rauzi, M., Wittbrodt, J., Leptin, M., 2015. Noninvasive In Toto Imaging of the Thymus Reveals Heterogeneous Migratory Behavior of Developing T Cells. J. Immunol. 195, 2177 LP2186. doi:10.4049/jimmunol.1500361

Baro, B., Deroost, K., Raiol, T., Brito, M., Almeida, A.C.G., de Menezes-Neto, A., Figueiredo, E.F.G., Alencar, A., Leitão, R., Val, F., Monteiro, W., Oliveira, A., Armengol, M.D.P., Fernández-Becerra, C., Lacerda, M. V, Del Portillo, H.A., 2017. Plasmodium vivax gametocytes in the bone marrow of an acute malaria patient and changes in the erythroid miRNA profile. PLoS Negl. Trop. Dis. 11, e0005365e0005365. doi:10.1371/journal.pntd.0005365

Bienenstock, J., McDermott, M.R., 2005. Bronchus- and nasal-associated lymphoid tissues. Immunol. Rev. 206, 22-31. doi:10.1111/j.0105-2896.2005.00299.x

Bockstal, V., Geurts, N., Magez, S., 2011a. Acute Disruption of Bone Marrow B Lymphopoiesis and Apoptosis of Transitional and Marginal Zone B Cells in the Spleen following a Blood-Stage Plasmodium chabaudi Infection in Mice. J. Parasitol. Res. 2011, 534697. doi:10.1155/2011/534697

Bockstal, V., Guirnalda, P., Caljon, G., Goenka, R., Telfer, J.C., Frenkel, D., Radwanska, M., 
Magez, S., Black, S.J., 2011b. T. brucei infection reduces B lymphopoiesis in bone marrow and truncates compensatory splenic lymphopoiesis through transitional B-cell apoptosis. PLoS Pathog. 7, e1002089-e1002089. doi:10.1371/journal.ppat.1002089

Bousso, P., Bhakta, N.R., Lewis, R.S., Robey, E., 2002. Dynamics of Thymocyte-Stromal Cell Interactions Visualized by Two-Photon Microscopy. Science. 296 (5574), 18761880. doi:10.1126/science. 1070945

Bousso, P., Robey, E.A., 2004. Dynamic Behavior of T Cells and Thymocytes in Lymphoid Organs as Revealed by Two-Photon Microscopy. Immunity 21, 349-355. doi: 10.1016/j.immuni.2004.08.005

Brouland, J., Audouin, J., Hofman, P., Le Tourneau, A., Basset, D., Rio, B., Zittoun, R., Diebold, J., 1996. Bone marrow involvement by disseminated toxoplasmosis in acquired immunodeficiency syndrome: The value of bone marrow trephine biopsy and immunohistochemistry for the diagnosis. Hum. Pathol. 27, 302-306. doi:10.1016/S0046-8177(96)90073-8

Buffet, P.A., Milon, G., Brousse, V., Correas, J.-M., Dousset, B., Couvelard, A., Kianmanesh, R., Farges, O., Sauvanet, A., Paye, F., Ungeheuer, M.-N., Ottone, C., Khun, H., Fiette, L., Guigon, G., Huerre, M., Mercereau-Puijalon, O., David, P.H., 2006. Ex vivo perfusion of human spleens maintains clearing and processing functions. Blood 107, 3745-3752. doi:10.1182/blood-2005-10-4094

Buffet, P.A., Safeukui, I., Milon. G., Mercereau-Puijalon, O., David, P.H., 2009. Retention of erythrocytes in the spleen: a double-edged process in human malaria. Curr Opin Hematol 16(3), 157-164. doi:10.1097/MOH.0b013e32832a1d4b

Bunting, M.D., Comerford, I., McColl, S.R., 2011. Finding their niche: chemokines directing cell migration in the thymus. Immunol. Cell Biol. 89, 185-196.

doi:10.1038/icb.2010.142

Caetano, S.S., Teixeira, T., Tadokoro, C.E., 2012. Intravital imaging of the mouse thymus using 2-photon Microscopy. J. Vis. Exp. e3504-e3504. doi:10.3791/3504

Caljon, G., Mabille, D., Stijlemans, B., De Trez, C., Mazzone, M., Tacchini-Cottier, F., Malissen, M., A Van Ginderachter, J., Magez, S., De Baetselier, P., Van Den Abbeele, J., 2018. Neutrophils enhance early Trypanosoma brucei infection onset. Sci. Rep. 8, 11203. doi:10.1038/s41598-018-29527-y

Caljon, G., Van Reet, N., De Trez, C., Vermeersch, M., Pérez-Morga, D., Van Den Abbeele, J., 2016. The Dermis as a Delivery Site of Trypanosoma brucei for Tsetse Flies. PLoS Pathog. 12, e1005744. doi:10.1371/journal.ppat.1005744

Calvi, L.M., Adams, G.B., Weibrecht, K.W., Weber, J.M., Olson, D.P., Knight, M.C., Martin, R.P., Schipani, E., Divieti, P., Bringhurst, F.R., Milner, L.A., Kronenberg, H.M., Scadden, D.T., 2003. Osteoblastic cells regulate the haematopoietic stem cell niche. Nature 425, 841-846. doi:10.1038/nature02040

Carbajosa, S., Gea, S., Chillón-Marinas, C., Poveda, C., Del Carmen Maza, M., Fresno, M., Gironès, N., 2017. Altered bone marrow lymphopoiesis and interleukin-6-dependent inhibition of thymocyte differentiation contribute to thymic atrophy during Trypanosoma cruzi infection. Oncotarget 8 (11), 17551-17561. doi:10.18632/oncotarget.14886

Cesta, M.F., 2006. Normal Structure, Function, and Histology of Mucosa-Associated Lymphoid Tissue. Toxicol. Pathol. 34, 599-608. doi:10.1080/01926230600865531

Chakravarty, S., Cockburn, I.A., Kuk, S., Overstreet, M.G., Sacci, J.B., Zavala, F., 2007. CD8+ T lymphocytes protective against malaria liver stages are primed in skin-draining lymph nodes. Nat Med 13, 1035-1041. doi:10.1038/nm1628

Chauhan, V.P., Stylianopoulos, T., Martin, J.D., Popović, Z., Chen, O., Kamoun, W.S., Bawendi, M.G., Fukumura, D., Jain, R.K., 2012. Normalization of tumour blood vessels 
improves the delivery of nanomedicines in a size-dependent manner. Nat. Nanotechnol. 7, 383-388. doi:10.1038/nnano.2012.45

Chieppa, M., Rescigno, M., Huang, A.Y.C., Germain, R.N., 2006. Dynamic imaging of dendritic cell extension into the small bowel lumen in response to epithelial cell TLR engagement. J. Exp. Med. 203, 2841-2852. doi:10.1084/jem.20061884

Chtanova T, Hampton HR, Waterhouse LA, Wood K, Tomura M, Miwa Y, Mackay CR, Brink R, P.T., 2014. Real-time interactive two-photon photoconversion of recirculating lymphocytes for discontinuous cell tracking in live adult mice. J Biophotonics 7(6), 425-433. doi:10.1002/jbio.201200175.

Chtanova, T., Han, S.-J., Schaeffer, M., van Dooren, G.G., Herzmark, P., Striepen, B., Robey, E.A., 2009. Dynamics of T cell, antigen-presenting cell, and pathogen interactions during recall responses in the lymph node. Immunity 31, 342-355. doi:10.1016/j.immuni.2009.06.023

Chtanova, T., Schaeffer, M., Han, S.-J., van Dooren, G.G., Nollmann, M., Herzmark, P., Chan, S.W., Satija, H., Camfield, K., Aaron, H., Striepen, B., Robey, E.A., 2008. Dynamics of neutrophil migration in lymph nodes during infection. Immunity $29,487-$ 496. doi:10.1016/j.immuni.2008.07.012

Coombes, J.L., Charsar, B.A., Han, S.-J., Halkias, J., Chan, S.W., Koshy, A.A., Striepen, B., Robey, E.A., 2013. Motile invaded neutrophils in the small intestine of Toxoplasma gondii-infected mice reveal a potential mechanism for parasite spread. Proc. Natl. Acad. Sci. U. S. A. 110, E1913-E1922. doi:10.1073/pnas.1220272110

Coombes, J.L., Robey, E.A., 2010. Dynamic imaging of host-pathogen interactions in vivo. Nat. Rev. Immunol. 10, 353. doi:10.1038/nri2746.

Coppi, A., Natarajan, R., Pradel, G., Bennett, B.L., James, E.R., Roggero, M.A., Corradin, G., Persson, C., Tewari, R., Sinnis, P., 2011. The malaria circumsporozoite protein has two functional domains, each with distinct roles as sporozoites journey from mosquito to mammalian host. J. Exp. Med. 208, 341-356. doi:10.1084/jem.20101488

Cotta-de-Almeida, V., Bonomo, A., Mendes-da-Cruz, D.A., Riederer, I., de Meis, J., LimaQuaresma, K.R.F., Vieira-de-Abreu, A., Villa-Verde, D.M.S., Savino, W., 2003.

Trypanosoma cruzi infection modulates intrathymic contents of extracellular matrix ligands and receptors and alters thymocyte migration. Eur. J. Immunol. 33, 2439-2448. doi:10.1002/eji.200323860

da Silva, H.B., de Salles, É.M., Panatieri, R.H., Boscardin, S.B., Rodríguez-Málaga, S.M., Álvarez, J.M., D’Império Lima, M.R., 2013. IFN- $\gamma$-Induced Priming Maintains LongTerm Strain-Transcending Immunity against Blood-Stage Plasmodium chabaudi; Malaria. J. Immunol. 191, 5160-5169. doi:10.4049/jimmunol.1300462

De Diego, J.A., Palau, M.T., Gamallo, C., Penin, P., 1998. Relationships between histopathological findings and phylogenetic divergence in Trypanosoma cruzi. Trop. Med. Int. Heal. 3, 222-233. doi:10.1111/j.1365-3156.1998.tb00275.x

de Meis, J., Aurélio Farias-de-Oliveira, D., Nunes Panzenhagen, P.H., Maran, N., VillaVerde, D.M.S., Morrot, A., Savino, W., 2012. Thymus atrophy and double-positive escape are common features in infectious diseases. J. Parasitol. Res. 2012, 574020. doi: $10.1155 / 2012 / 574020$

De Niz, M., Meibalan, E., Mejia, P., Ma, S., Brancucci, N.M.B., Agop-Nersesian, C., Mandt, R., Ngotho, P., Hughes, K.R., Waters, A.P., Huttenhower, C., Mitchell, J.R., Martinelli, R., Frischknecht, F., Seydel, K.B., Taylor, T., Milner, D., Heussler, V.T., Marti, M., 2018. Plasmodium gametocytes display homing and vascular transmigration in the host bone marrow. Sci. Adv. 4, eaat3775. doi:10.1126/sciadv.aat3775

De Niz, M., Spadin, F., Marti, M., Stein, J. V, Frenz, M., Frischknecht, F., 2019. Toolbox for In Vivo Imaging of Host-Parasite Interactions at Multiple Scales. Trends Parasitol. 35, 
193-212. doi: 10.1016/j.pt.2019.01.002

De Niz, M., Ullrich, A.-K., Heiber, A., Blancke Soares, A., Pick, C., Lyck, R., Keller, D., Kaiser, G., Prado, M., Flemming, S., del Portillo, H., Janse, C.J., Heussler, V.,

Spielmann, T., 2016. The machinery underlying malaria parasite virulence is conserved between rodent and human malaria parasites. Nat Commun 7:11659.

doi:10.1038/ncomms11659.

De Trez, C., Magez, S., Akira, S., Ryffel, B., Carlier, Y., Muraille, E., 2009. iNOS-Producing Inflammatory Dendritic Cells Constitute the Major Infected Cell Type during the Chronic Leishmania major Infection Phase of C57BL/6 Resistant Mice. PLOS Pathog. 5, e1000494. doi:10.1371/journal.ppat.1000494.

del Portillo, H.A., Ferrer, M., Brugat, T., Martin-Jaular, L., Langhorne, J., Lacerda, M.V.G., 2012. The role of the spleen in malaria. Cell. Microbiol. 14, 343-355. doi:10.1111/j.1462-5822.2011.01741.X

Derricott, H., Luu, L., Fong, W.Y., Hartley, C.S., Johnston, L.J., Armstrong, S.D., Randle, N., Duckworth, C.A., Campbell, B.J., Wastling, J.M., Coombes, J.L., 2019. Developing a 3D intestinal epithelium model for livestock species. Cell Tissue Res. 375, 409-424. doi:10.1007/s00441-018-2924-9

Duffier, Y., Lorthiois, A., Cisteró, P., Dupuy, F., Jouvion, G., Fiette, L., Mazier, D., Mayor, A., Lavazec, C., Moreno Sabater, A., 2016. A humanized mouse model for sequestration of Plasmodium falciparum sexual stages and in vivo evaluation of gametocytidal drugs. Sci. Rep. 6, 35025. doi:10.1038/srep35025

Ehrlich, L.I.R., Oh, D.Y., Weissman, I.L., Lewis, R.S., 2009. Differential contribution of chemotaxis and substrate restriction to segregation of immature and mature thymocytes. Immunity 31, 986-998. doi:10.1016/j.immuni.2009.09.020

Elkhafif N., Voss, B., Hammam, O., Yehia, H., Mansy, S., Akl, M., Boehm, S., Mahmoud, S., El Bendary, O., El Fandy, G., 2010. Homing of transplanted bone marrow cells in livers of Schistosoma mansoni-infected mice. APMIS 118, 277-287. doi:10.1111/j.1600-0463.2010.02585.x

Engwerda, C.R., Beattie, L., Amante, F.H., 2016. The importance of the spleen in malaria. Trends Parasitol. 21, 75-80. doi:10.1016/j.pt.2004.11.008

Erslev, A.J., 1971. The Search for Erythropoietin. N. Engl. J. Med. 284, 849-850. doi:10.1056/NEJM197104152841510

Farfour, E., Charlotte, F., Settegrana, C., Miyara, M., Buffet, P., 2012. The extravascular compartment of the bone marrow: a niche for Plasmodium falciparum gametocyte maturation? Malar. J. 11, 1-4. doi:10.1186/1475-2875-11-285

Farias-de-Oliveira, D.A., Cotta-de-Almeida, V., Villa-Verde, D.M.S., Riederer, I., Meis, J. de, Savino, W., 2013a. Fibronectin modulates thymocyte-thymic epithelial cell interactions following Trypanosoma cruzi infection. Mem. Inst. Oswaldo Cruz 108, 825-831. doi:10.1590/0074-0276130071

Farias-de-Oliveira, D.A., Villa-Verde, D.M.S., Nunes Panzenhagen, P.H., Silva dos Santos, D., Berbert, L.R., Savino, W., de Meis, J., 2013b. Caspase-8 and caspase-9 mediate thymocyte apoptosis in Trypanosoma cruzi acutely infected mice. J. Leukoc. Biol. 93, 227-234. doi:10.1189/jlb.1211589

Felizardo, A.A., Caldas, I.S., Mendonça, A.A.S., Gonçalves, R. V, Tana, F.L., Almeida, L.A., Novaes, R.D., 2018. Impact of Trypanosoma cruzi infection on nitric oxide synthase and arginase expression and activity in young and elderly mice. Free Radic. Biol. Med. 129, 227-236. doi:10.1016/j.freeradbiomed.2018.09.031

Ferrer, M., Martin-Jaular, L., Calvo, M., del Portillo, H.A., 2012. Intravital Microscopy of the Spleen: Quantitative Analysis of Parasite Mobility and Blood Flow. J. Vis. Exp. 3609. doi: $10.3791 / 3609$ 
Francelin, C., Paulino, L.C., Gameiro, J., Verinaud, L., 2011. Effects of Plasmodium berghei on thymus: High levels of apoptosis and premature egress of CD4+CD8+ thymocytes in experimentally infected mice. Immunobiology $216,1148-1154$. doi:

10.1016/j.imbio.2011.03.009

Gameiro, J., Nagib, P.R.A., Andrade, C.F., Villa-Verde, D.M.S., Silva-Barbosa, S.D., Savino, W., Costa, F.T.M., Verinaud, L., 2009. Changes in cell migration-related molecules expressed by thymic microenvironment during experimental Plasmodium berghei infection: consequences on thymocyte development. Immunology 129, 248-256. doi:10.1111/j.1365-2567.2009.03177.x

Gibson, V.B., Benson, R.A., Bryson, K.J., McInnes, I.B., Rush, C.M., Grassia, G., Maffia, P., Jenkinson, E.J., White, A.J., Anderson, G., Brewer, J.M., Garside, P., 2012. A novel method to allow noninvasive, longitudinal imaging of the murine immune system in vivo. Blood 119, 2545-2551. doi:10.1182/blood-2011-09-378356

Graewe, S., Stanway, R.R., Rennenberg, A., Heussler, V.T., 2012. Chronicle of a death foretold: Plasmodium liver stage parasites decide on the fate of the host cell. FEMS Microbiol Rev 36(1), 111-130. doi: 10.1111/j.1574-6976.2011.00297.x

Grayson, M.H., Chaplin, D.D., Karl, I.E., Hotchkiss, R.S., 2001. Confocal fluorescent intravital microscopy of the murine spleen. J. Immunol. Methods 256, 55-63. doi: 10.1016/S0022-1759(01)00437-9

Gueirard, P., Tavares, J., Thiberge, S., Bernex, F., Ishino, T., Milon, G., Franke-Fayard, B., Janse, C.J., Ménard, R., Amino, R., 2010. Development of the malaria parasite in the skin of the mammalian host. Proc. Natl. Acad. Sci. U. S. A. 107, 18640-18645. doi:10.1073/pnas.1009346107

Habila, N., Muhammad, A., Ndidi, U.S., Chechet, G.D., Aimola, I.A., Olalekan, B.A., 2014. Clastogenic effects of Trypanosoma brucei brucei and Trypanosoma evansi mixed infection in bone marrow of Wistar rats. Res. Vet. Sci. 97, 550-553. doi: 10.1016/j.rvsc.2014.09.018

Hackney, J.A., Charbord, P., Brunk, B.P., Stoeckert, C.J., Lemischka, I.R., Moore, K.A., 2002. A molecular profile of a hematopoietic stem cell niche. Proc. Natl. Acad. Sci. U. S. A. 99, 13061-13066. doi:10.1073/pnas.192124499

Hampton, H.R., Bailey, J., Tomura, M., Brink, R., Chtanova, T., 2015. Microbe-dependent lymphatic migration of neutrophils modulates lymphocyte proliferation in lymph nodes. Nat. Commun. 6, 7139. doi:10.1038/ncomms8139

Haque, L., Villanueva, M., Russo, A., Yuan, Y., Lee, E.-J., Topal, J., Podoltsev, N., 2018. A rare case of visceral leishmaniasis in an immunocompetent traveler returning to the United States from Europe. PLoS Negl. Trop. Dis. 12, e0006727. doi:10.1371/journal.pntd.0006727.

Hellal, M., Kundu, S., 2013. Visceral leishmaniasis involving the bone marrow. Blood 122, 627 LP-627. doi:10.1182/blood-2013-02-484022

Hess, I., Boehm, T., 2012. Intravital Imaging of Thymopoiesis Reveals Dynamic LymphoEpithelial Interactions. Immunity 36, 298-309. doi:10.1016/j.immuni.2011.12.016

Huldt, G., Gard, S., Olovson, S.G., 1973. Effect of Toxoplasma gondii on the Thymus. Nature 244, 301-303. doi:10.1038/244301a0

Hurrell, B.P., Schuster, S., Grün, E., Coutaz, M., Williams, R.A., Held, W., Malissen, B., Malissen, M., Yousefi, S., Simon, H.-U., Müller, A.J., Tacchini-Cottier, F., 2015. Rapid Sequestration of Leishmania mexicana by Neutrophils Contributes to the Development of Chronic Lesion. PLoS Pathog. 11, e1004929-e1004929. doi:10.1371/journal.ppat.1004929

Itkin, T., Gur-Cohen, S., Spencer, J.A., Schajnovitz, A., Ramasamy, S.K., Kusumbe, A.P., Ledergor, G., Jung, Y., Milo, I., Poulos, M.G., Kalinkovich, A., Ludin, A., Kollet, O., 
Shakhar, G., Butler, J.M., Rafii, S., Adams, R.H., Scadden, D.T., Lin, C.P., Lapidot, T., 2016. Distinct bone marrow blood vessels differentially regulate haematopoiesis. Nature 532, 323-328. doi:10.1038/nature17624

Jeong, H.-S., Jones, D., Liao, S., Wattson, D.A., Cui, C.H., Duda, D.G., Willett, C.G., Jain, R.K., Padera, T.P., 2015. Investigation of the Lack of Angiogenesis in the Formation of Lymph Node Metastases. J. Natl. Cancer Inst. 107, djv155. doi:10.1093/jnci/djv155

Joice, R., Nilsson, S.K., Montgomery, J., Dankwa, S., Egan, E., Morahan, B., Seydel, K.B., Bertuccini, L., Alano, P., Williamson, K.C., Duraisingh, M.T., Taylor, T.E., Milner, D.A., Marti, M., 2014. Plasmodium falciparum transmission stages accumulate in the human bone marrow. Sci. Transl. Med. 6, 244re5-244re5.

doi:10.1126/scitranslmed.3008882

Jones, C., Leday, T. V, 2014. Schistosomal eggs identified on bone marrow biopsy. Blood 124, 1219. doi:10.1182/blood-2014-06-582767

Joshi, A.D., Raymond, T., Coelho, A.L., Kunkel, S.L., Hogaboam, C.M., 2008. A systemic granulomatous response to Schistosoma mansoni eggs alters responsiveness of bone marrow-derived macrophages to Toll-like receptor agonists. J. Leukoc. Biol. 83, 314324. doi:10.1189/jlb.1007689

Jung, C., Hugot, J.-P., Barreau, F., 2010. Peyer's Patches: The Immune Sensors of the Intestine. Int. J. Inflam. 2010, 823710. doi:10.4061/2010/823710

Jung, Y., Spencer, J.A., Raphael, A.P., Wu, J.W., Alt, C., Runnels, J.R., Geiger, B., Lin, C.P., 2018. Intravital Imaging of Mouse Bone Marrow: Hemodynamics and Vascular Permeability BT - Intravital Imaging of Dynamic Bone and Immune Systems : Methods and Protocols, in: Ishii, M. (Ed.), . Springer New York, New York, NY, pp. 11-22. doi:10.1007/978-1-4939-7762-8_2

Kamal, KA; Fata, JS; Kilroy S:, Skelly, RR; Ansari, A., 1989. Modulatory effects of Schistosoma mansoni infection on bone marrow granulopoietic and erythropoietic activity in mice. Ann Clin Lab Sci 19, 56-64.

Kedrin, D., Gligorijevic, B., Wyckoff, J., Verkhusha, V. V, Condeelis, J., Segall, J.E., van Rheenen, J., 2008. Intravital imaging of metastatic behavior through a mammary imaging window. Nat. Methods 5, 1019-1021. doi:10.1038/nmeth.1269

Kim, S., Lin, L., Brown, G.A.J., Hosaka, K., Scott, E.W., 2017. Extended time-lapse in vivo imaging of tibia bone marrow to visualize dynamic hematopoietic stem cell engraftment. Leukemia 31, 1582-1592. doi:10.1038/leu.2016.354

Köhler, A., Schmithorst, V., Filippi, M.-D., Ryan, M.A., Daria, D., Gunzer, M., Geiger, H., 2009. Altered cellular dynamics and endosteal location of aged early hematopoietic progenitor cells revealed by time-lapse intravital imaging in long bones. Blood 114, 290-298. doi:10.1182/blood-2008-12-195644.

Kolesnikov, M., Farache, J., Shakhar, G., 2015. Intravital two-photon imaging of the gastrointestinal tract. J. Immunol. Methods 421, 73-80. doi: 10.1016/j.jim.2015.03.008

Kubo, T., Shinke, T., Okamura, T., Hibi, K., Nakazawa, G., Morino, Y., Shite, J., Fusazaki, T., Otake, H., Kozuma, K., Ioji, T., Kaneda, H., Serikawa, T., Kataoka, T., Okada, H., Akasaka, T., Investigators, O., 2017. Optical frequency domain imaging vs. intravascular ultrasound in percutaneous coronary intervention (OPINION trial): oneyear angiographic and clinical results. Eur. Heart J. 38, 3139-3147. doi:10.1093/eurheartj/ehx351

Kugler, D.G., Flomerfelt, F.A., Costa, D.L., Laky, K., Kamenyeva, O., Mittelstadt, P.R., Gress, R.E., Rosshart, S.P., Rehermann, B., Ashwell, J.D., Sher, A., Jankovic, D., 2016. Systemic toxoplasma infection triggers a long-term defect in the generation and function of naive T lymphocytes. J. Exp. Med. 213, 3041-3056. doi:10.1084/jem.20151636

Kumar, Perikala; Vasei, Mohammad; Sadeghipour, Alireza; Sadeghi, Esmaeel; 
Soleimanpour, Hossein; Mousavi, Abdullah; Tabatabaei, Ameer; Rizvi, M., 2007.

Visceral Leishmaniasis: bone marrow biopsy findings. J. Pediatr. Hematol. Oncol. 29, 77-80. doi:10.1097/MPH.0b013e31803076a8.

Ladi, E., Herzmark, P., Robey, E., 2008. In situ imaging of the mouse thymus using 2-photon microscopy. J. Vis. Exp. 652. doi:10.3791/652

Ladi, E., Schwickert, T.A., Chtanova, T., Chen, Y., Herzmark, P., Yin, X., Aaron, H., Chan, S.W., Lipp, M., Roysam, B., Robey, E.A., 2008. Thymocyte-dendritic cell interactions near sources of CCR7 ligands in the thymic cortex. J. Immunol., 181(10) 7014-7023. doi: 10.4049/jimmunol.181.10.7014.

Lavazec, C., 2017. Molecular mechanisms of deformability of Plasmodium-infected erythrocytes. Curr. Opin. Microbiol. 40, 138-144. doi:10.1016/j.mib.2017.11.011

Lavazec, C., Alano, P., 2014. Uncovering the hideout of malaria sexual parasites. Blood 123, 954 LP-955. doi:10.1182/blood-2013-12-545418

Lavazec, C., Deplaine, G., Safeukui, I., Perrot, S., Milon, G., Mercereau-Puijalon, O., David, P.H., Buffet, P., 2013. Microsphiltration: A Microsphere Matrix to Explore Erythrocyte Deformability BT - Malaria: Methods and Protocols, in: Ménard, R. (Ed.), . Humana Press, Totowa, NJ, pp. 291-297. doi:10.1007/978-1-62703-026-7_20

Le, V.-H., Lee, S., Lee, S., Wang, T., Hyuk Jang, W., Yoon, Y., Kwon, S., Kim, H., Lee, S.W., Hean Kim, K., 2017. In vivo longitudinal visualization of bone marrow engraftment process in mouse calvaria using two-photon microscopy. Sci. Rep. 7, 44097. doi:10.1038/srep44097

Lee, M.S.J., Maruyama, K., Fujita, Y., Konishi, A., Lelliott, P.M., Itagaki, S., Horii, T., Lin, J., Khan, S.M., Kuroda, E., Akira, S., Ishii, K.J., Coban, C., 2017. Plasmodium products persist in the bone marrow and promote chronic bone loss. Sci. Immunol. 2, eaam8093. doi:10.1126/sciimmunol.aam8093

Lee, R.S., Waters, A.P., Brewer, J.M., 2018. A cryptic cycle in haematopoietic niches promotes initiation of malaria transmission and evasion of chemotherapy. Nat. Commun. 9, 1689. doi:10.1038/s41467-018-04108-9

Leite-de-Moraes, M.C., Hontebeyrie-Joskowicz, M., Dardenne, M., Savino, W., 1992. Modulation of thymocyte subsets during acute and chronic phases of experimental Trypanosoma cruzi infection. Immunology 77, 95-98.

Lemischka, I.R., Moore, K.A., 2003. Stem Cells: Interactive niches. Nature 425, 778-779. doi:10.1038/425778a

León, B., López-Bravo, M., Ardavín, C., 2007. Monocyte-Derived Dendritic Cells Formed at the Infection Site Control the Induction of Protective T Helper 1 Responses against Leishmania. Immunity 26, 519-531. doi:10.1016/j.immuni.2007.01.017

Liou, H.L.R., Myers, J.T., Barkauskas, D.S., Huang, A.Y., 2012. Intravital imaging of the mouse popliteal lymph node. J. Vis. Exp. 3720. doi:10.3791/3720

Lo Celso, C., Fleming, H.E., Wu, J.W., Zhao, C.X., Miake-Lye, S., Fujisaki, J., Côté, D., Rowe, D.W., Lin, C.P., Scadden, D.T., 2009. Live-animal tracking of individual haematopoietic stem/progenitor cells in their niche. Nature 457, 92-96. doi: 10.1038/nature07434

Lo Celso, Wu, J.W., Lin, C.P., 2009. In vivo imaging of hematopoietic stem cells and their microenvironment. J. Biophotonics 2, 619-631. doi:10.1002/jbio.200910072

Lo Celso, C., Lin, C.P., Scadden, D.T., 2011. In vivo imaging of transplanted hematopoietic stem and progenitor cells in mouse calvarium bone marrow. Nat. Protoc. 6, 1-14. doi:10.1038/nprot.2010.168

Mabbott, N., Sternberg, J., 1995. Bone marrow nitric oxide production and development of anemia in Trypanosoma brucei-infected mice. Infect. Immun. 63, 1563-1566.

Marcondes, M.C.G., Borelli, P., Yoshida, N., Russo, M., 2000. Acute Trypanosoma cruzi 
infection is associated with anemia, thrombocytopenia, leukopenia, and bone marrow hypoplasia: reversal by nifurtimox treatment. Microbes Infect. 2, 347-352. doi: $10.1016 /$ S1286-4579(00)00333-6

Markus, M.B., 2018. New Evidence for Hypnozoite-Independent Plasmodium vivax Malarial Recurrences. Trends Parasitol. 34, 1015-1016. doi:10.1016/j.pt.2018.08.010.

Martin-Jaular, L., Ferrer, M., Calvo, M., Rosanas-Urgell, A., Kalko, S., Graewe, S., Soria, G., Cortadellas, N., Ordi, J., Planas, A., Burns, J., Heussler, V., del Portillo, H.A., 2011. Strain-specific spleen remodelling in Plasmodium yoelii infections in Balb/c mice facilitates adherence and spleen macrophage-clearance escape. Cell. Microbiol. 13, 109122. doi:10.1111/j.1462-5822.2010.01523.x

Matthys, R., Perren, S.M., 2009. Internal fixator for use in the mouse. Injury 40, S103-S109. doi:10.1016/j.injury.2009.10.044

Mayor, A., Alano, P., 2015. Bone marrow reticulocytes: a Plasmodium affair? Blood 125, 1203 LP-1205. doi:10.1182/blood-2014-12-614123

Mazo, I.B., Gutierrez-Ramos, J.C., Frenette, P.S., Hynes, R.O., Wagner, D.D., von Andrian, U.H., 1998. Hematopoietic progenitor cell rolling in bone marrow microvessels: parallel contributions by endothelial selectins and vascular cell adhesion molecule 1. J. Exp. Med. 188, 465-474. doi:10.1084/jem.188.3.465

Mebius, R.E., Kraal, G., 2005. Structure and function of the spleen. Nat. Rev. Immunol. 5, 606-616. doi:10.1038/nri1669

Meijer, E.F.J., Jeong, H.-S., Pereira, E.R., Ruggieri, T.A., Blatter, C., Vakoc, B.J., Padera, T.P., 2017. Murine chronic lymph node window for longitudinal intravital lymph node imaging. Nat. Protoc. 12, 1513-1520. doi:10.1038/nprot.2017.045

Mempel, T.R., Henrickson, S.E., von Andrian, U.H., 2004. T-cell priming by dendritic cells in lymph nodes occurs in three distinct phases. Nature 427, 154-159. doi: $10.1038 /$ nature 02238

Mendes-da-Cruz, D.A., de Meis, J., Cotta-de-Almeida, V., Savino, W., 2003. Experimental Trypanosoma cruzi infection alters the shaping of the central and peripheral T-cell repertoire. Microbes Infect. 5, 825-832. doi: 10.1016/S1286-4579(03)00156-4

Mendes-da-Cruz, D.A., Silva, J.S., Cotta-de-Almeida, V., Savino, W., 2006. Altered thymocyte migration during experimental acute Trypanosoma cruzi infection: combined role of fibronectin and the chemokines CXCL12 and CCL4. Eur. J. Immunol. 36, 14861493. doi:10.1002/eji.200535629

Messina, V., Valtieri, M., Rubio, M., Falchi, M., Mancini, F., Mayor, A., Alano, P., Silvestrini, F., 2018. Gametocytes of the Malaria Parasite Plasmodium falciparum Interact With and Stimulate Bone Marrow Mesenchymal Cells to Secrete Angiogenetic Factors. Front. Cell. Infect. Microbiol. 8, 50. doi:10.3389/fcimb.2018.00050

Moran, I., Grootveld, A.K., Nguyen, A., Phan, T.G., 2019. Subcapsular Sinus Macrophages: The Seat of Innate and Adaptive Memory in Murine Lymph Nodes. Trends Immunol. 40,35-48. doi: 10.1016/j.it.2018.11.004

Morrot, A., Barreto de Albuquerque, J., Berbert, L.R., de Carvalho Pinto, C.E., de Meis, J., Savino, W., 2012. Dynamics of Lymphocyte Populations during Trypanosoma cruzi Infection: From Thymocyte Depletion to Differential Cell Expansion/Contraction in Peripheral Lymphoid Organs. J. Trop. Med. 2012, 747185. doi:10.1155/2012/747185

Müller, U., Schaub, G.A., Mossmann, H., Köhler, G., Carsetti, R., Hölscher, C., 2018. Immunosuppression in Experimental Chagas Disease Is Mediated by an Alteration of Bone Marrow Stromal Cell Function During the Acute Phase of Infection. Front. Immunol. 9, 2794. doi:10.3389/fimmu.2018.02794

Naissant, B., Dupuy, F., Duffier, Y., Lorthiois, A., Duez, J., Scholz, J., Buffet, P., Merckx, A., Bachmann, A., Lavazec, C., 2016. Plasmodium falciparum STEVOR 
phosphorylation regulates host erythrocyte deformability enabling malaria parasite transmission. Blood 127, e42-e53. doi:10.1182/blood-2016-01-690776

Neveu, G., Dupuy, F., Ladli, M., Barbieri, D., Naissant, B., Richard, C., Martins, R.M., Lopez-Rubio, J.-J., Bachmann, A., Verdier, F., Lavazec, C., 2018. Plasmodium falciparum gametocyte-infected erythrocytes do not adhere to human primary erythroblasts. Sci. Rep. 8, 17886. doi:10.1038/s41598-018-36148-y

Niesner, R.A., Andresen, V., Gunzer, M., 2008. Intravital two-photon microscopy: focus on speed and time resolved imaging modalities. Immunol. Rev. 221, 7-25. doi:10.1111/j.1600-065X.2008.00582.x

Nitschke, C., Garin, A., Kosco-Vilbois, M., Gunzer, M., 2008. 3D and 4D imaging of immune cells in vitro and in vivo. Histochem. Cell Biol. 130, 1053-1062. doi:10.1007/s00418-008-0520-x

Nunes-Alves, C., Nobrega, C., Behar, S.M., Correia-Neves, M., 2013. Tolerance has its limits: how the thymus copes with infection. Trends Immunol. 34, 502-510. doi:10.1016/j.it.2013.06.004

Obaldia 3rd, N., Meibalan, E., Sa, J.M., Ma, S., Clark, M.A., Mejia, P., Moraes Barros, R.R., Otero, W., Ferreira, M.U., Mitchell, J.R., Milner, D.A., Huttenhower, C., Wirth, D.F., Duraisingh, M.T., Wellems, T.E., Marti, M., 2018. Bone Marrow Is a Major Parasite Reservoir in Plasmodium vivax Infection. MBio 9, e00625-18. doi: 10.1128/mBio.00625-18

Obeid, M., Franetich, J.-F., Lorthiois, A., Gego, A., Grüner, A.C., Tefit, M., Boucheix, C., Snounou, G., Mazier, D., 2013. Skin-draining lymph node priming is sufficient to induce sterile immunity against pre-erythrocytic malaria. EMBO Mol. Med. 5, 250-263. doi:10.1002/emmm.201201677

Obishakin, E., de Trez, C., Magez, S., 2014. Chronic Trypanosoma congolense infections in mice cause a sustained disruption of the B-cell homeostasis in the bone marrow and spleen. Parasite Immunol. 36, 187-198. doi:10.1111/pim.12099

Oh, J., Shin, J.S., 2015. The role of dendritic cells in central tolerance. Immune Netw. 15(3): 111-120. doi:10.4110/in.2015.15.3.111

Ojok, L., Kaeufer-Weiss, I., Weiss, E., 2001. Bone Marrow Response to Acute and Chronic Trypanosoma congolense Infection in Multimammate Rats (Mastomys coucha). J. Comp. Pathol. 124, 149-158. doi: 10.1053/jcpa.2000.0445

Otake, H., Kubo, T., Takahashi, H., Shinke, T., Okamura, T., Hibi, K., Nakazawa, G., Morino, Y., Shite, J., Fusazaki, T., Kozuma, K., Ioji, T., Kaneda, H., Akasaka, T., 2018. Optical Frequency Domain Imaging Versus Intravascular Ultrasound in Percutaneous Coronary Intervention (OPINION Trial): Results From the OPINION Imaging Study. JACC Cardiovasc. Imaging 11, 111-123. doi:10.1016/j.jcmg.2017.06.021

Pérez, A.R., Roggero, E., Nicora, A., Palazzi, J., Besedovsky, H.O., del Rey, A., Bottasso, O.A., 2007. Thymus atrophy during Trypanosoma cruzi infection is caused by an immuno-endocrine imbalance. Brain. Behav. Immun. 21, 890-900. doi:10.1016/j.bbi.2007.02.004

Peters, N.C., Egen, J.G., Secundino, N., Debrabant, A., Kimblin, N., Kamhawi, S., Lawyer, P., Fay, M.P., Germain, R.N., Sacks, D., 2008. In vivo imaging reveals an essential role for neutrophils in leishmaniasis transmitted by sand flies. Science, 321, 970-974. doi:10.1126/science.1159194

Picot, J., Ndour, P.A., Lefevre, S.D., El Nemer, W., Tawfik, H., Galimand, J., Da Costa, L., Ribeil, J.A., de Montalembert, M., Brousse, V., Le Pioufle, B., Buffet, P., Le Van Kim, C., Français, O., 2015. A biomimetic microfluidic chip to study the circulation and mechanical retention of red blood cells in the spleen. Am. J. Hematol. 90, 339-345. doi:10.1002/ajh.23941 
Preham, O., Pinho, F.A., Pinto, A.I., Rani, G.F., Brown, N., Hitchcock, I.S., Goto, H., Kaye, P.M., 2018. CD4+ T cells alter the stromal microenvironment and repress medullary erythropoiesis in murine visceral leishmaniasis. Front. Immunol. 9:2958. doi: $10.3389 /$ fimmu. 2018.02958

Radtke, A.J., Kastenmüller, W., Espinosa, D.A., Gerner, M.Y., Tse, S.-W., Sinnis, P., Germain, R.N., Zavala, F.P., Cockburn, I.A., 2015. Lymph-node resident CD8 $\alpha+$ dendritic cells capture antigens from migratory malaria sporozoites and induce CD8+ T cell responses. PLoS Pathog. 11, e1004637-e1004637.

doi:10.1371/journal.ppat.1004637

Ramdani, G., Naissant, B., Thompson, E., Breil, F., Lorthiois, A., Dupuy, F., Cummings, R., Duffier, Y., Corbett, Y., Mercereau-Puijalon, O., Vernick, K., Taramelli, D., Baker, D.A., Langsley, G., Lavazec, C., 2015. cAMP-Signalling Regulates GametocyteInfected Erythrocyte Deformability Required for Malaria Parasite Transmission. PLOS Pathog. 11, e1004815. doi:10.1371/journal.ppat.1004815.

Reismann, D., Stefanowski, J., Günther, R., Rakhymzhan, A., Matthys, R., Nützi, R., Zehentmeier, S., Schmidt-Bleek, K., Petkau, G., Chang, H.-D., Naundorf, S., Winter, Y., Melchers, F., Duda, G., Hauser, A.E., Niesner, R.A., 2017. Longitudinal intravital imaging of the femoral bone marrow reveals plasticity within marrow vasculature. Nat. Commun. 8, 2153. doi:10.1038/s41467-017-01538-9

Ribeiro-Gomes, F.L., Peters, N.C., Debrabant, A., Sacks, D.L., 2012. Efficient capture of infected neutrophils by dendritic cells in the skin inhibits the early anti-leishmania response. PLoS Pathog. 8, e1002536-e1002536. doi:10.1371/journal.ppat.1002536

Ribeiro-Gomes, F.L., Sacks, D., 2012. The influence of early neutrophil-Leishmania interactions on the host immune response to infection. Front. Cell. Infect. Microbiol. 2, 59. doi:10.3389/fcimb.2012.00059

Rigat-Brugarolas, L.G., Elizalde-Torrent, A., Bernabeu, M., De Niz, M., Martin-Jaular, L., Fernandez-Becerra, C., Homs-Corbera, A., Samitier, J., Del Portillo, H.A., 2014. A functional microengineered model of the human splenon-on-a-chip. Lab Chip 14, 17151724. doi:10.1039/c3lc51449h

Ritsma, L., Steller, E.J.A., Beerling, E., Loomans, C.J.M., Zomer, A., Gerlach, C., Vrisekoop, N., Seinstra, D., van Gurp, L., Schäfer, R., Raats, D.A., de Graaff, A., Schumacher, T.N., de Koning, E.J.P., Rinkes, I.H.B., Kranenburg, O., Rheenen, J. van, 2012. Intravital Microscopy Through an Abdominal Imaging Window Reveals a PreMicrometastasis Stage During Liver Metastasis. Sci. Transl. Med. 4, 158ra145. doi:10.1126/scitranslmed.3004394

Ritsma, L., Steller, E.J.A., Ellenbroek, S.I.J., Kranenburg, O., Borel Rinkes, I.H.M., van Rheenen, J., 2013. Surgical implantation of an abdominal imaging window for intravital microscopy. Nat. Protoc. 8, 583. doi:10.1038/nprot.2013.026.

Rogers, N.J., Hall, B.S., Obiero, J., Targett, G.A., Sutherland, C.J., 2000. A model for sequestration of the transmission stages of Plasmodium falciparum: adhesion of gametocyte-infected erythrocytes to human bone marrow cells. Infect. Immun. 68, 3455-3462. doi:10.1128/iai.68.6.3455-3462.2000

Ross, J.O., Melichar, H.J., Halkias, J., Robey, E.A., 2016. Studying T Cell Development in Thymic Slices BT - T-Cell Development: Methods and Protocols, in: Bosselut, R., S. Vacchio, M. (Eds.), . Springer New York, New York, NY, pp. 131-140. doi:10.1007/978-1-4939-2809-5_11

Ruddle, N.H., Akirav, E.M., 2009. Secondary lymphoid organs: responding to genetic and environmental cues in ontogeny and the immune response. J. Immunol. 183, 2205-2212. doi:10.4049/jimmunol.0804324

Savino, W., 2006. The thymus is a common target organ in infectious diseases. PLoS Pathog. 
2, e62-e62. doi:10.1371/journal.ppat.0020062

Savino, W., Leite-de-Moraes, M.D.C., Hontebeyrie-Joskowicz, M., Dardenne, M., 1989.

Studies on the thymus in chagas' disease. Eur. J. Immunol. 19, 1727-1733.

doi:10.1002/eji.1830190930

Secklehner, J., Lo Celso, C., Carlin, L.M., 2017. Intravital microscopy in historic and contemporary immunology. Immunol. Cell Biol. 95, 506-513. doi:10.1038/icb.2017.25

Silva Pereira, S., Trindade, S., De Niz, M., Figueiredo, L.M., 2019. Tissue tropism in parasitic diseases. Open Biol. 9, 190036. doi:10.1098/rsob.190036

Smalley, M.E., Abdalla, S., Brown, J., 1981. The distribution of Plasmodium falciparum in the peripheral blood and bone marrow of Gambian children. Trans. R. Soc. Trop. Med. Hyg. 75, 103-105. doi: 10.1016/0035-9203(81)90019-5.

Souza, B.S. d F., Azevedo, C.M., d Lima, R.S., Kaneto, C.M., Vasconcelos, J.F., Guimarães, E.T., dos Santos, R.R., Soares, M.B.P., 2014. Bone marrow cells migrate to the heart and skeletal muscle and participate in tissue repair after Trypanosoma cruzi infection in mice. Int. J. Exp. Pathol. 95, 321-329. doi:10.1111/iep.12089

Spencer, J.A., Ferraro, F., Roussakis, E., Klein, A., Wu, J., Runnels, J.M., Zaher, W., Mortensen, L.J., Alt, C., Turcotte, R., Yusuf, R., Côté, D., Vinogradov, S.A., Scadden, D.T., Lin, C.P., 2014. Direct measurement of local oxygen concentration in the bone marrow of live animals. Nature 508, 269-273. doi:10.1038/nature13034

Stein, J. V, F. Gonzalez, S., 2017. Dynamic intravital imaging of cell-cell interactions in the lymph node. J. Allergy Clin. Immunol. 139, 12-20. doi:10.1016/j.jaci.2016.11.008

Stijlemans, B., Brys, L., Korf, H., Bieniasz-Krzywiec, P., Sparkes, A., Vansintjan, L., Leng, L., Vanbekbergen, N., Mazzone, M., Caljon, G., Van Den Abbeele, J., Odongo, S., De Trez, C., Magez, S., Van Ginderachter, J.A., Beschin, A., Bucala, R., De Baetselier, P., 2016. MIF-Mediated Hemodilution Promotes Pathogenic Anemia in Experimental African Trypanosomosis. PLoS Pathog. 12, e1005862-e1005862. doi:10.1371/journal.ppat.1005862

Thalhofer, C.J., Chen, Y., Sudan, B., Love-Homan, L., Wilson, M.E., 2011. Leukocytes infiltrate the skin and draining lymph nodes in response to the protozoan Leishmania infantum chagasi. Infect. Immun. 79, 108-117. doi:10.1128/IAI.00338-10

Thalhofer, C.J., Graff, J.W., Love-Homan, L., Hickerson, S.M., Craft, N., Beverley, S.M., Wilson, M.E., 2010. In vivo imaging of transgenic Leishmania parasites in a live host. J. Vis. Exp. 1980. doi:10.3791/1980

Torcellan, T., Stolp, J., Chtanova, T., 2017. In Vivo Imaging Sheds Light on Immune Cell Migration and Function in Cancer. Front. Immunol. 8, 309. doi:10.3389/fimmu.2017.00309

Trentin, J.J., 1971. Determination of bone marrow stem cell differentiation by stromal hemopoietic inductive microenvironments (HIM). Am. J. Pathol. 65, 621-628.

Turcotte, R., Alt, C., Mortensen, L.J., Lin, C.P., 2014. Characterization of multiphoton microscopy in the bone marrow following intravital laser osteotomy. Biomed. Opt. Express 5, 3578-3588. doi:10.1364/BOE.5.003578

Van den Broeck, W., Derore, A., Simoens, P., 2006. Anatomy and nomenclature of murine lymph nodes: Descriptive study and nomenclatory standardization in BALB/cAnNCrl mice. J. Immunol. Methods 312, 12-19. doi:10.1016/j.jim.2006.01.022

Vladymyrov, M., Abe, J., Moalli, F., Stein, J. V, Ariga, A., 2016. Real-time tissue offset correction system for intravital multiphoton microscopy. J. Immunol. Methods 438, 3541. doi: 10.1016/j.jim.2016.08.004

Vogler, N., Heuke, S., Bocklitz, T.W., Schmitt, M., Popp, J., 2015. Multimodal Imaging Spectroscopy of Tissue. Annu. Rev. Anal. Chem. 8, 359-387. doi:10.1146/annurevanchem-071114-040352 
Waseem S, Ur-Rehman Kashif, Kumar Ramesh, M.T., 2016. Hemozoin Enhances Maturation of Murine Bone Marrow Derived Macrophages and Myeloid Dendritic Cells. Iran. J. Immunol. 13, 1-8. doi:IJIc13i1A1.

Watanabe, P. da S., Trevizan, A.R., Silva-Filho, S.E., Góis, M.B., Garcia, J.L., Cuman, R.K.N., Breithaupt-Faloppa, A.C., Sant Ana, D. de M.G., Nogueira de Melo, G. de A., 2018. Immunocompetent host develops mild intestinal inflammation in acute infection with Toxoplasma gondii. PLoS One 13, e0190155-e0190155. doi:10.1371/journal.pone.0190155

Wickramasinghe, S.N., Phillips, R.E., Looareesuwan, S., Warrell, D.A., Hughes, M., 1987. The bone marrow in human cerebral malaria: parasite sequestration within sinusoids. $\mathrm{Br}$. J. Haematol. 66, 295-306. doi:10.1111/j.1365-2141.1987.00295.x

Xu, C., Shen, Y., Littman, D.R., Dustin, M.L., Velázquez, P., 2012. Visualization of mucosal homeostasis via single- and multiphoton intravital fluorescence microscopy. J. Leukoc. Biol. 92, 413-419. doi:10.1189/jlb.0711344

Yun, S., Tearney, G., de Boer, J., Iftimia, N., Bouma, B., 2003. High-speed optical frequency-domain imaging. Opt. Express 11, 2953-2963. doi:10.1364/oe.11.002953

Zhang, J., Niu, C., Ye, L., Huang, H., He, X., Tong, W.-G., Ross, J., Haug, J., Johnson, T., Feng, J.Q., Harris, S., Wiedemann, L.M., Mishina, Y., Li, L., 2003. Identification of the haematopoietic stem cell niche and control of the niche size. Nature 425, 836-841. doi:10.1038/nature02041

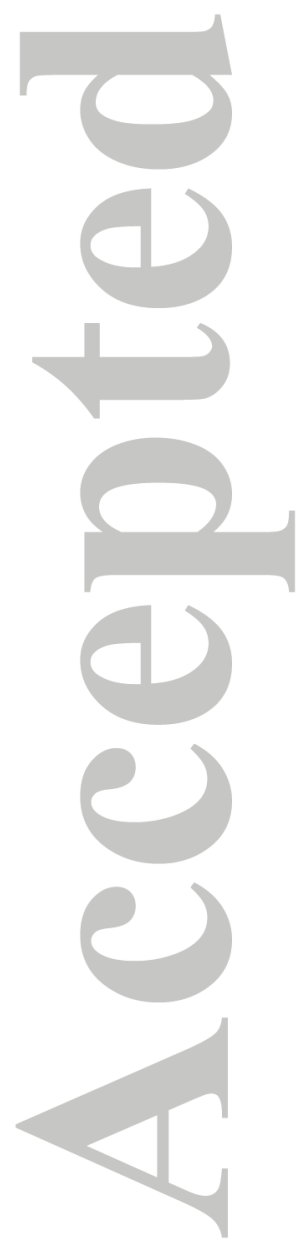



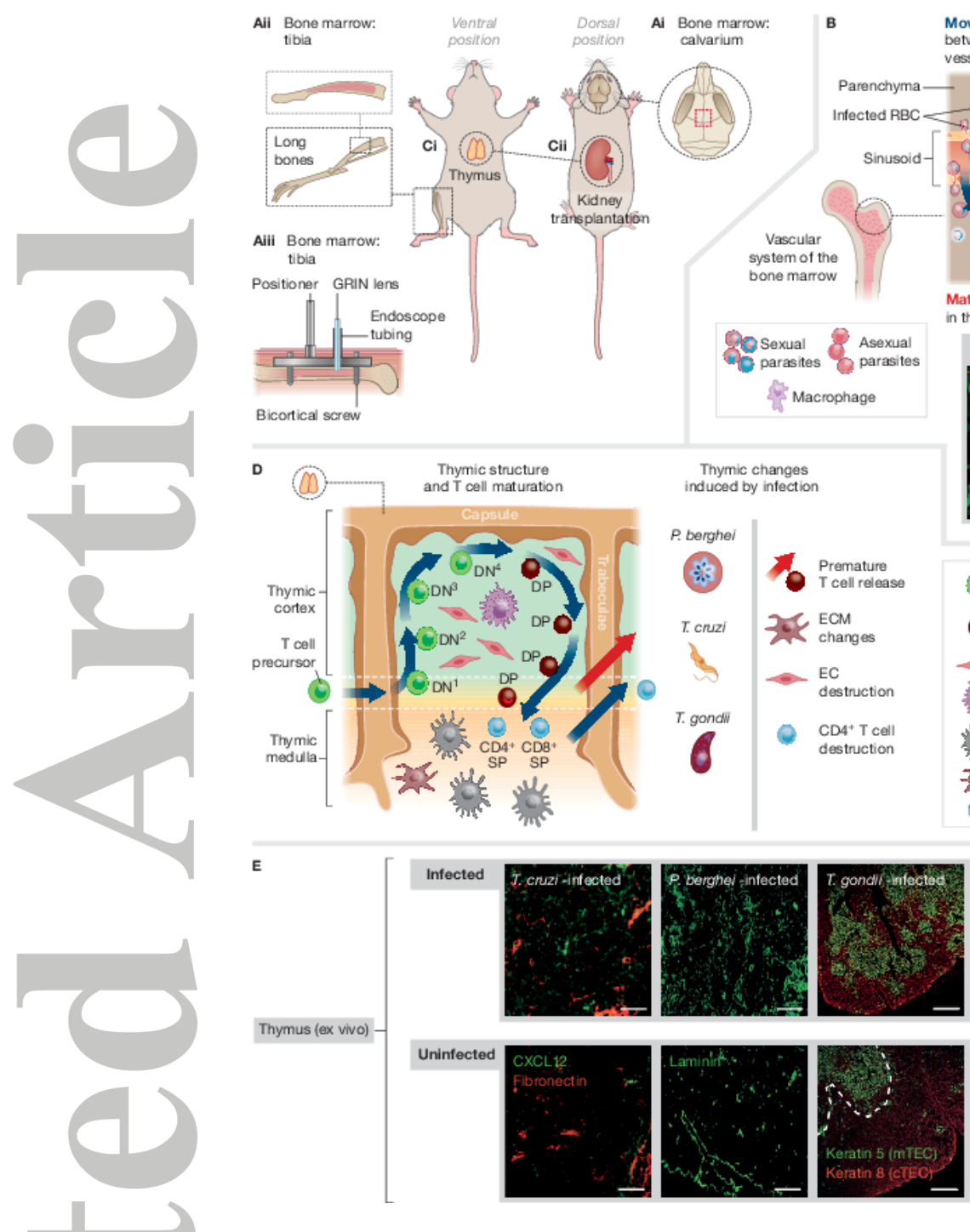

Figure 1. Windows for IVM and biological findings on primary lymphoid organs (PLOs): bone marrow (A-B) and thymus (C-D). Ai) The calvarial BM is located close to the intersection of the cortical and sagittal sutures, and the bifurcation of the sagittal suture. Access requires an incision of the scalp to expose the cranium, and either direct access with an objective, or the implantation of a glass window. Methods to access long bones include Aii) ventral exposure of the tibia and femur, with careful separation of tendons and muscles to allow access to the BM close to the bone head. This can allow for IVM imaging with or without a chronic window; and Aiii) surgical implantation of a device to allow entry of an endoscope tubing and a GRIN lens for long term imaging and access to deeper sites of the BM of various bones. B) Key findings in parasitology by IVM include the observation of Plasmodium berghei gametocyte homing to and development within the extravascular space of the BM of long bones. Primary figure shows a still frame from an IVM visualizing mCherry-tagged $P$. berghei gametocytes in the BM of a UBC-GFP reporter mouse (Adapted from De Niz et al., 2018). The other lymphoid organ is the thymus (C), which is located in the thorax, above the heart. Direct access to the thymus is challenging. A technique used for

IVM is the transplantation of the thymus to the kidney capsule, and visualization of the kidney capsule using a dorso-lateral window. Imaging can be done in the dorsal position. D) Although no IVM has been reported for the thymus in the context of parasitology, various studies have shown that parasites including T. cruzi, T. gondii and Plasmodium alter the thymic architecture, inducing phenomena such as thymic atrophy, accelerated $\mathrm{T}$ cell release 
(T. cruzi and Plasmodium), and increased endothelial cell and CD4+ T cell destruction ( $T$. gondii). E) Ex vivo images of the thymus of Top panel: control (left) and T. cruzi-infected mice (right) showing increased deposition of CXCL12 (green) and fibronectin (red) in infected mice, consistent with altered thymocyte migration (Adapted from Mendes-da-Cruz, et al., 2006). Middle panel: control (left) and P. berghei -infected mice (right) showing increased laminin deposition (green) in the thymus of infected mice, consistent with changes in extracellular matrix components upon infection (Adapted from Gameiro et al., 2009).

Bottom panel: control (left) and $T$. gondii-infected mice (right) showing increased convolution of the cortico-medullary border upon infection with $T$. gondii. Labelling shows keratin 5 and 8, markers of medullary and cortical thymic endothelial cells respectively (Adapted from Kugler et al., 2016). (Abbreviations. Referring to T cell receptor: DN: double negative; DP: double positive; SP: single positive. Other abbreviations: ECM: extracellular matrix; EC: endothelial cell.) All original images were published under a Creative Commons

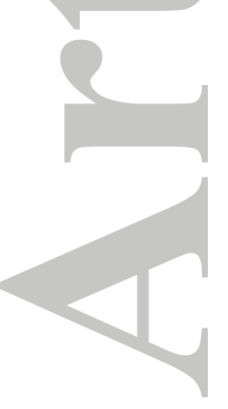
Attribution (CCA) license, and/or reproduced with permission.

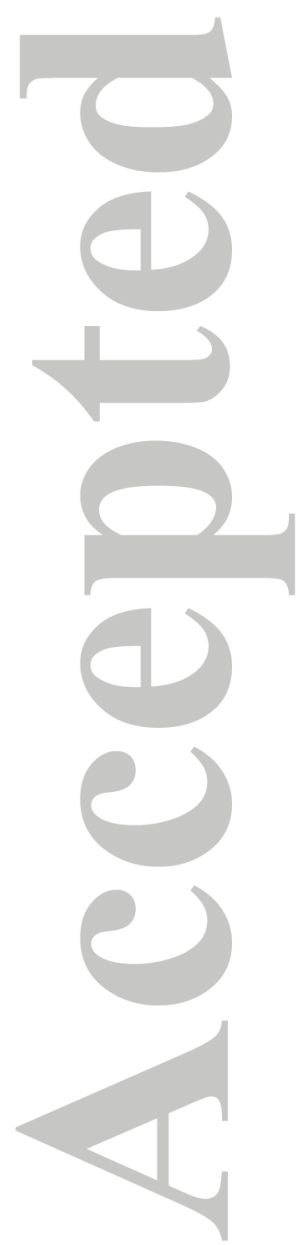



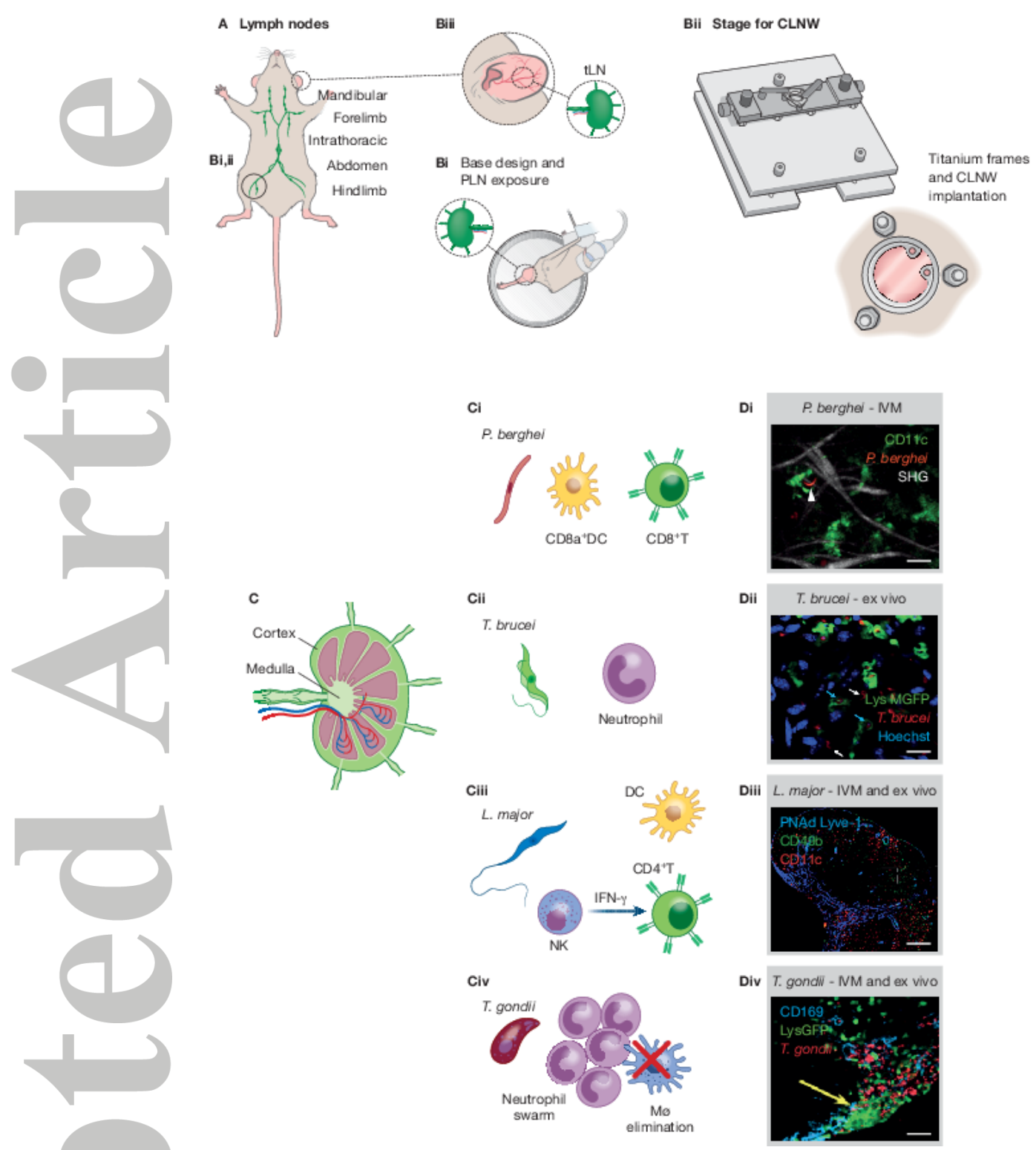

Figure 2. Windows for IVM, and biological findings on secondary lymphoid organs (SLOs): lymph nodes (2A-D). A) 22 LNs have been identified in mice in the head and neck, the forelimb, the hindlimb, the intrathoracic region, and the abdomen. One of the preferred sites for LN imaging is the popliteal lymph node (PLN), close to the knee joint. Various methods exist to image the PLN: Bi) direct visualization following stabilization for which a customized stage is recommended; Bii) the generation of a chronic LN window (CLNW) with a customized stage that prevents rotational changes and motion-induced artefacts, and relies on the surgical implantation of titanium frames holding the LN sandwiched in-between. An alternative method is Biii) transplantation of the $\mathrm{LN}$ to the ear pinna, followed by direct imaging. Biological findings by IVM in the lymph nodes include $\mathrm{Ci}$ ) sporozoite antigen presentation by $\mathrm{LN}$ resident $\mathrm{CD} 8 \alpha^{+}$dendritic cells necessary for $\mathrm{CD}^{+} \mathrm{T}$ cell priming; $\mathrm{Cii}$ ) that monocyte-derived DCs increase in neutropenic mice, and are correlated with better Tcell-mediated Leishmania mexicana control, and that NK cells from the LN cortex aid in the activation of parasite-specific CD4+T cells against Leishmania major; and Ciii) neutrophil

swarm formation in $T$. gondii infections, resulting in macrophage elimination in the subscapular sinus of the LN. Primary images show Di) Maximum intensity projection of $P$. berghei sporozoites (red) and CD11c+ antigen-presenting cells (green) at the draining lymph 
node of CD11c-EYFP reporter mice, 5 hours post-intradermal inoculation - imaged by IVM (Adapted from Radtke et al., 2015). Dii) Confocal image of T. brucei AnTat 1.1 (red) uptake by Lys-MGFP+ neutrophils (green) in the dermis of infected mice. (Adapted from Caljon et al., 2018). Diii) Confocal image of ear draining lymph node of mouse 12 hours following infection with L. major. Staining shows peripheral node addressin (PNAd) and Lyve1 (blue), CD49b (highly expressed in NK cells, (green)), and CD11c+ antigen presenting cells (DCs).

In chosen region, numerous NK cells and DCs are in physical contact. (Adapted from Bajenoff et al., 2006). Div) Confocal image of a lymph node 3 hours after infection of a mouse with $T$. gondii parasites. Neutrophils (Lys-GFP) are shown swarming in areas adjacent to T. gondii (red), and macrophages (CD169, blue). (Adapted from Chtanova et al., 2008). All original images were published under a Creative Commons Attribution (CCA) license,

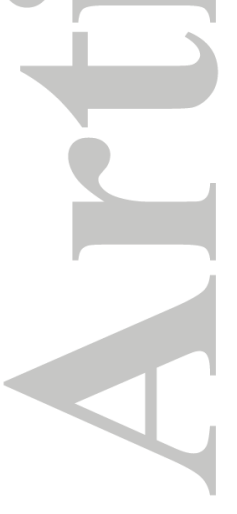
and/or reproduced with permission.

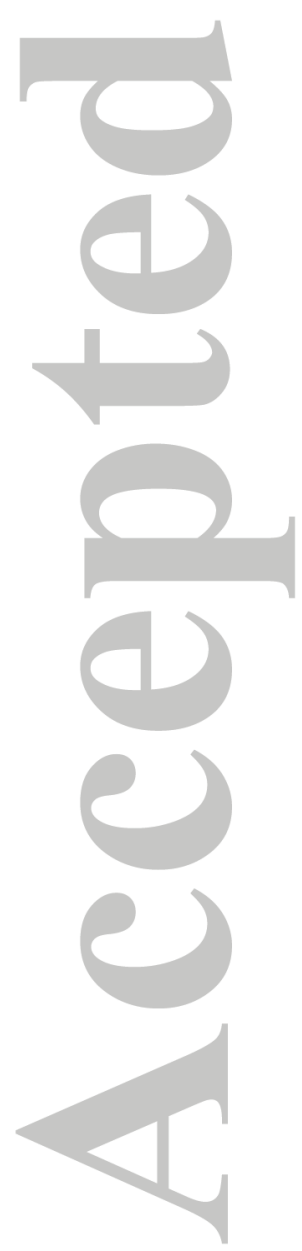


Ai Spleen and GALT

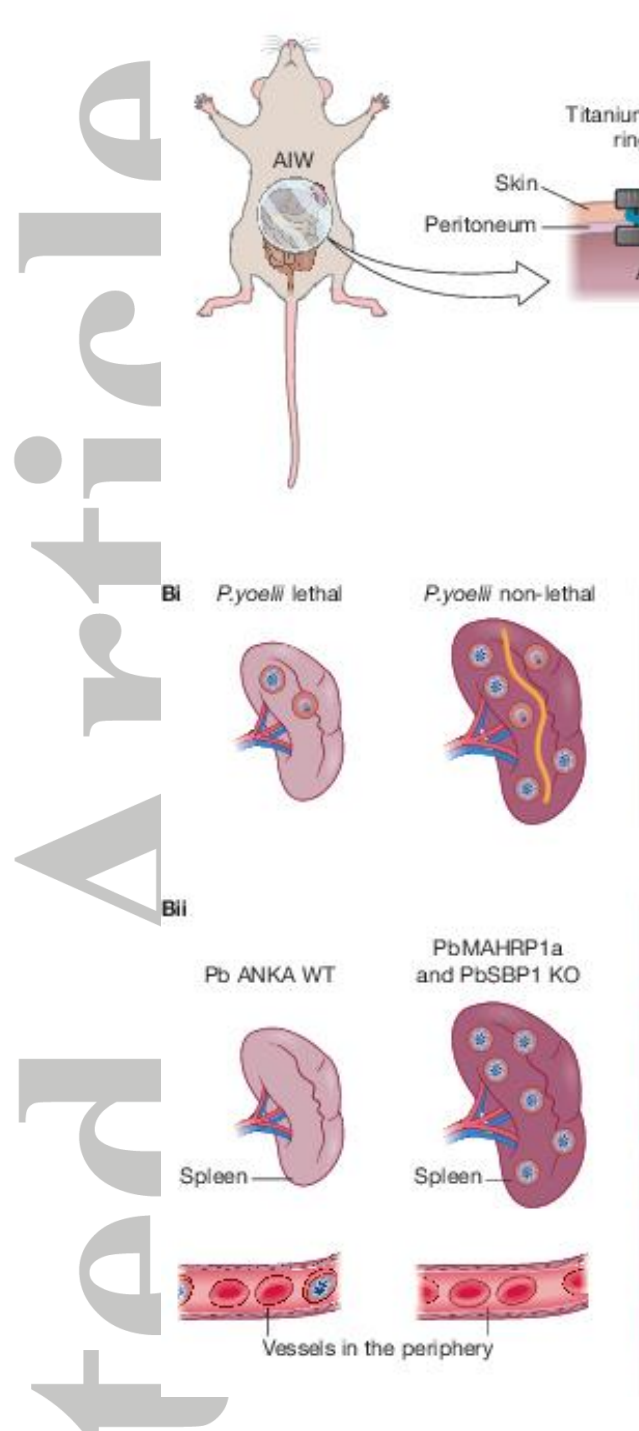

Ail Inverted microscope

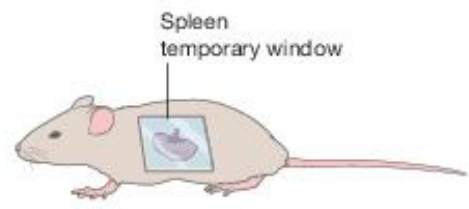

Aiii Upright microscope

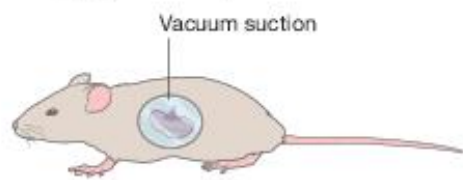

C GALT: vili and mucosal epithelium

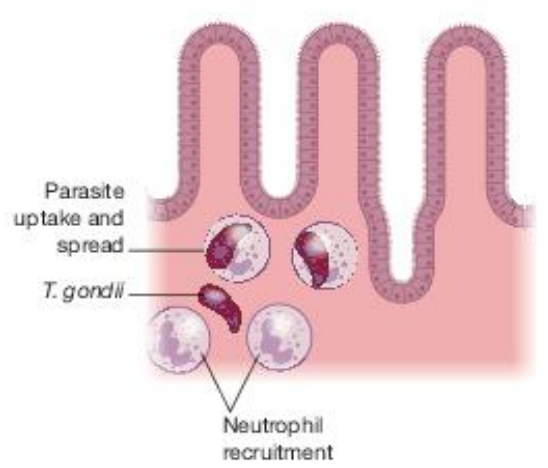

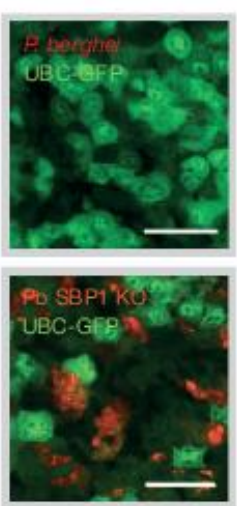
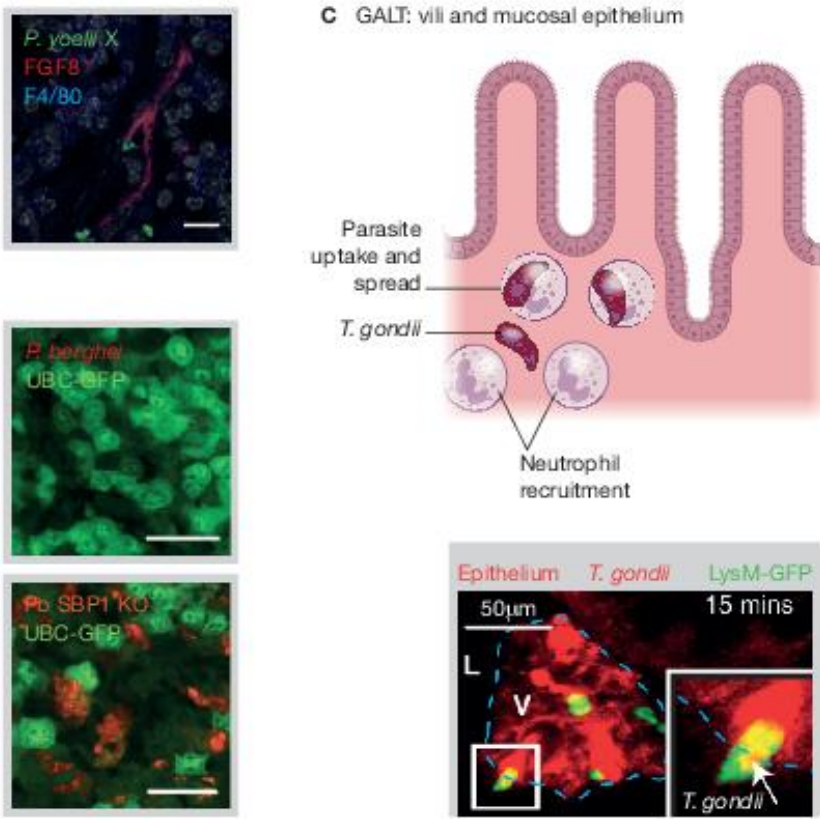

Figure 3. Windows for IVM, and biological findings on secondary lymphoid organs (SLOs): spleen (2A-D) and GALT (E). Spleen. Ai) shows the abdominal intravital window, which gives access to the abdominal organs including the gut and the spleen (on the dorso-ventral side). The chronic window consists on the implantation of titanium rings to enable imaging. Aii) shows a temporary window consisting on the exposure of the spleen, and visualization through a coverslip using an inverted microscope. Aiii) is an alternative whereby the mouse can be imaged using an upright microscope. For stabilization, the coverslip and organ are immobilized using a vacuum. Main biological findings in the spleen using IVM involve

Plasmodium infections, namely $\mathrm{Bi}$ ) that lethal and non-lethal strains of $P$. yoelii differentially remodel the spleen. The non-lethal strain induces the formation of a barrier of fibroblastic origin which protects the parasites from phagocytosis, causing vast splenomegaly. Primary image shows the spleen of a mouse infected with non-lethal P. yoelii 17X (green) at day 3 post-infection, showing FGF8 as a marker of a barrier of fibroblastic origin (red) and F4/80 macrophages (blue). (Adapted from Martin-Jaular et al., 2011). Bii) Shows that at early synchronized infections, $P$. berghei ANKA schizonts sequester in the vascular periphery, avoiding the spleen, while parasites unable to sequester ( $\mathrm{Pb} \Delta \mathrm{MAHRP} 1 \mathrm{a}$ and $\mathrm{Pb} \Delta \mathrm{SBP} 1)$ are absent from the vasculature in the periphery, but are present in vast numbers in the spleen, where they are eliminated. Primary images (middle and bottom panels) show spleens of reporter mice (UBC-GFP, green) infected with $P$. berghei $\mathrm{WT}$ and $\mathrm{Pb} \Delta \mathrm{SBP} 1$ (red), 16-18 
hours following intravenous injection of synchronized schizonts. (Adapted from De Niz et al., 2016). GALT. The GALT can be observed using various windows including the AIW (Ai). Biological findings in parasitology by IVM are restricted to observation of $T$. gondii, whereby C) neutrophil recruitment was observed to the vili and mucosal epithelium. Within neutrophils, $T$. gondii survives and disseminates to other organs. Primary image shows $T$. gondii-containing LysM-GFP cells (yellow) migrating across the intestinal epithelium (red). Images were obtained by two-photon microscopy. (Adapted from Coombes et al., 2013). All original images were published under a Creative Commons Attribution (CCA) license, and/or reproduced with permission.
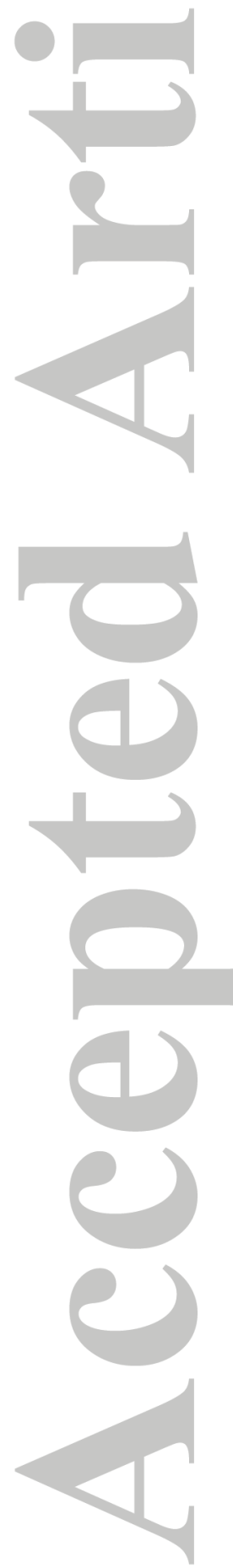
TABLE 1 Optical windows for accessing primary and secondary lymphoid organs for intravital microscopy.

\begin{tabular}{|c|c|c|c|c|c|}
\hline Organ & Technique & Key points & Complexity & Advantages & Limitations \\
\hline \multirow[t]{6}{*}{$\begin{array}{l}\text { Bone } \\
\text { marrow }\end{array}$} & $\begin{array}{l}\text { Direct imaging } \\
\text { on the calvarium }\end{array}$ & $\begin{array}{l}\text { Easy surgical } \\
\text { access. }\end{array}$ & Low & $\begin{array}{l}\text { Easy access. } \\
\text { Low risk. } \\
\text { Fast surgical } \\
\text { procedure. }\end{array}$ & $\begin{array}{l}\text { Sutures required } \\
\text { after each } \\
\text { imaging session. } \\
\text { This can cause } \\
\text { scarring, and is a } \\
\text { challenge to } \\
\text { longitudinal } \\
\text { imaging. }\end{array}$ \\
\hline & $\begin{array}{l}\text { Calvarial } \\
\text { window }\end{array}$ & $\begin{array}{l}\text { Prevents re- } \\
\text { growth of the } \\
\text { membrane layer. } \\
\text { Involves } \\
\text { implantation of a } \\
\text { window. } \\
\text { Cortical bone can } \\
\text { be removed. }\end{array}$ & Low & $\begin{array}{l}\text { Easy to perform. } \\
\text { Allows } \\
\text { longitudinal } \\
\text { imaging. }\end{array}$ & $\begin{array}{l}\text { None if limited } \\
\text { to the calvarium. }\end{array}$ \\
\hline & $\begin{array}{l}\text { Direct imaging } \\
\text { of the tibia, or } \\
\text { incorporation of } \\
\text { a window. }\end{array}$ & $\begin{array}{l}\text { Allows access to } \\
\text { long bones. }\end{array}$ & $\begin{array}{l}\text { Very high. } \\
\text { Surgery } \\
\text { difficult to } \\
\text { perform. }\end{array}$ & $\begin{array}{l}\text { Allows imaging } \\
\text { marrow of long } \\
\text { bones. }\end{array}$ & $\begin{array}{l}\text { Requires a long } \\
\text { and complex } \\
\text { surgical } \\
\text { procedure. }\end{array}$ \\
\hline & $\begin{array}{l}\text { Window for } \\
\text { LIMB }\end{array}$ & $\begin{array}{l}\text { Micro-endoscopic } \\
\text { multi-photon } \\
\text { imaging method } \\
\text { using GRIN } \\
\text { lenses. }\end{array}$ & High. & $\begin{array}{l}\text { Allows imaging } \\
\text { sites deep within } \\
\text { the calvarium, } \\
\text { tibia, and femur. }\end{array}$ & $\begin{array}{l}\text { Difficult to } \\
\text { perform. }\end{array}$ \\
\hline & $\begin{array}{l}\text { Dorso-lateral } \\
\text { window for } \\
\text { kidney capsule. }\end{array}$ & $\begin{array}{l}\text { Requires } \\
\text { transplantation of } \\
\text { thymus to kidney } \\
\text { capsule. }\end{array}$ & Very high. & $\begin{array}{l}\text { Allows imaging of } \\
\text { the thymus. }\end{array}$ & $\begin{array}{l}\text { Different milieu } \\
\text { at kidney that } \\
\text { may not } \\
\text { represent the } \\
\text { thymic } \\
\text { environment. }\end{array}$ \\
\hline & $\begin{array}{l}\text { Teleost fish } \\
\text { models }\end{array}$ & $\begin{array}{l}\text { Allow imaging } \\
\text { the entire thymus. }\end{array}$ & Low. & $\begin{array}{l}\text { Allows } \\
\text { longitudinal } \\
\text { imaging of the } \\
\text { entire thymus and } \\
\text { visualization of T } \\
\text { cell dynamics } \\
\text { throughout all } \\
\text { developmental } \\
\text { stages. }\end{array}$ & $\begin{array}{l}\text { Require the use } \\
\text { (and suitability) } \\
\text { of fish models. }\end{array}$ \\
\hline \multirow[t]{2}{*}{$\begin{array}{l}\text { Lymph } \\
\text { nodes }\end{array}$} & $\begin{array}{l}\text { Direct imaging } \\
\text { of popliteal } \\
\text { lymph node }\end{array}$ & $\begin{array}{l}\text { Allow imaging of } \\
\text { cell-cell } \\
\text { interactions in the } \\
\text { three } \\
\text { compartments of } \\
\text { the lymph node }\end{array}$ & High & $\begin{array}{l}\text { Extensive use and } \\
\text { detailed protocols } \\
\text { available. } \\
\text { Significant } \\
\text { lymphatic } \\
\text { drainage from the } \\
\text { footpad thus a } \\
\text { good location to } \\
\text { image pathogens } \\
\text { and cells arrival }\end{array}$ & $\begin{array}{l}\text { Require good } \\
\text { surgical skills to } \\
\text { expose the LNs } \\
\text { Customized stage } \\
\text { to support mice } \\
\text { in the } \\
\text { microscope } \\
\text { Temporary }\end{array}$ \\
\hline & $\begin{array}{l}\text { Chronic lymph } \\
\text { node window }\end{array}$ & $\begin{array}{l}\text { Allow imaging of } \\
\text { the inguinal LNs }\end{array}$ & $\begin{array}{l}\text { Very high. } \\
\text { Surgery } \\
\text { difficult to } \\
\text { perform. }\end{array}$ & $\begin{array}{l}\text { Allows } \\
\text { longitudinal } \\
\text { imaging without } \\
\text { uncompromised }\end{array}$ & $\begin{array}{l}\text { The setup is } \\
\text { complex. } \\
\text { Requires } \\
\text { significant }\end{array}$ \\
\hline
\end{tabular}




\begin{tabular}{|c|c|c|c|c|c|}
\hline & & & & $\begin{array}{l}\text { blood flow and/or } \\
\text { vessel integrity } \\
\text { Minimal local } \\
\text { inflammation and } \\
\text { vascular } \\
\text { remodelling }\end{array}$ & $\begin{array}{l}\text { surgical } \\
\text { experience. }\end{array}$ \\
\hline 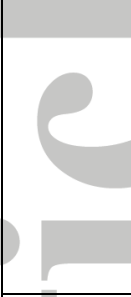 & $\begin{array}{l}\text { Transplantation } \\
\text { on ear pinna }\end{array}$ & $\begin{array}{l}\text { Allows easy } \\
\text { access due to } \\
\text { transplantation at } \\
\text { the ear pinna. }\end{array}$ & High. & $\begin{array}{l}\text { Allows non- } \\
\text { invasive } \\
\text { longitudinal } \\
\text { imaging. } \\
\text { Preserves } \\
\text { lymphatic and } \\
\text { vascular supply. }\end{array}$ & $\begin{array}{l}\text { Transplantation } \\
\text { can be } \\
\text { unsuccessful. } \\
\text { Requires good } \\
\text { surgical skills. }\end{array}$ \\
\hline \multirow[t]{3}{*}{$\begin{array}{l}\text { Spleen } \\
\text { and } \\
\text { GALT }\end{array}$} & $\begin{array}{l}\text { Abdominal } \\
\text { imaging window } \\
\text { (AIW) }\end{array}$ & $\begin{array}{l}\text { Requires surgical } \\
\text { implantation in } \\
\text { the abdomen. }\end{array}$ & Very high. & $\begin{array}{l}\text { Allows for } \\
\text { longitudinal } \\
\text { imaging without } \\
\text { disturbing } \\
\text { physiological } \\
\text { processes. }\end{array}$ & $\begin{array}{l}\text { The setup is } \\
\text { complex. } \\
\text { Requires } \\
\text { significant } \\
\text { surgical } \\
\text { experience. }\end{array}$ \\
\hline & $\begin{array}{l}\text { Temporary } \\
\text { splenic window }\end{array}$ & $\begin{array}{l}\text { Consists on } \\
\text { adhering a } \\
\text { window directly } \\
\text { to the spleen. }\end{array}$ & Medium. & Fast procedure. & $\begin{array}{l}\text { Requires good } \\
\text { surgical skills. } \\
\text { Extreme care } \\
\text { needed for the } \\
\text { exposure of the } \\
\text { spleen to avoid } \\
\text { vascular collapse } \\
\text { or } \\
\text { exsanguination. }\end{array}$ \\
\hline & $\begin{array}{l}\text { Temporary } \\
\text { intestinal } \\
\text { window }\end{array}$ & $\begin{array}{l}\text { Allows } \\
\text { observation of the } \\
\text { intestines and } \\
\text { Peyers Patches. }\end{array}$ & Medium. & $\begin{array}{l}\text { Straightforward } \\
\text { surgery. }\end{array}$ & $\begin{array}{l}\text { Care should be } \\
\text { taken to avoid } \\
\text { damaging } \\
\text { vasculature and } \\
\text { intestinal } \\
\text { epithelium, as } \\
\text { well as } \\
\text { dehydration. } \\
\text { Requires control } \\
\text { of peristaltic } \\
\text { motion. }\end{array}$ \\
\hline
\end{tabular}

